\title{
401(k)s and Household Saving: New Evidence from the Survey of Consumer Finances
}

\author{
Karen M. Pence \\ Federal Reserve Board of Governors \\ Karen.Pence@frb.gov \\ December 2001
}

\begin{abstract}
Although households have invested billions in 401(k) accounts, these balances may not be new saving if workers invest money that they would have saved in the program's absence. In this paper, I assess the effect of the 401(k) program on saving by comparing changes in the wealth of 401(k) eligible and ineligible households over the 1989-1998 period using data from the Survey of Consumer Finances (SCF). This comparison may yield misleading estimates of the effect of 401(k)s on saving if eligible households have a higher taste for saving than ineligible households or if they begin the 1989-1998 period with greater amounts of wealth. I adjust for these potential biases by constructing subjective measures of saving taste from questions on the SCF and by transforming the wealth measure with the inverse hyperbolic sine. Incorporating these adjustments suggests that $401(\mathrm{k})$ s have little to no effect on saving.

If 401(k)s do not increase saving, where do 401(k) balances come from? I examine two plausible margins of substitution: household substitution of $401(\mathrm{k})$ s for other assets and firm substitution of 401(k)s for defined-benefit pensions. I find weak evidence that households fund their 401(k) accounts, at least in part, by decreasing their holdings of real assets. However, I find no evidence that 401(k) balances stem from firms replacing traditional defined benefit pensions with 401(k) plans.
\end{abstract}

John Karl Scholz, Yuichi Kitamura and John Sabelhaus provided immeasurable help throughout this project. I am grateful to the editor, an anonymous referee, Gilbert Bassett, Brian Bucks, Martin David, Eric Engen, Bill Gale, Art Goldberger, Bob Haveman, Joe Hendrickson, John B. Jones, John Kennan, Brian Knight, Roger Koenker, Rob Lemke, Arik Levinson, Charles Manski, Paul Menchik, Brian Pence, Jean Prijatel, Larry Radbill, Gautam Tripathi, Steven Venti and Tom Wiseman for helpful comments. Surachai Khitatrakun provided essential assistance in calculating defined benefit pension values. I am indebted to Arthur Kennickell and the Federal Reserve Board staff for developing and documenting the Survey of Consumer Finances. Generous financial support was provided by the Social Science Research Council Program in Applied Economics, funded by the MacArthur Foundation, and the Christensen Award in Empirical Economics. The views presented are mine alone and do not necessarily represent those of the Federal Reserve Board or its staff. 


\section{INTRODUCTION}

The 401(k) program was introduced in 1978 to encourage personal saving for retirement and to help raise the U.S. savings rate. ${ }^{1}$ Originally the program was viewed as a supplement to employer-provided pension plans. However, over time these plans have become the primary employer-sponsored retirement vehicle for many Americans. By 1996, household balances in 401(k) accounts exceeded one trillion dollars. ${ }^{2}$

The 401(k) program features strong inducements for saving, including tax-deferred contributions and earnings, convenience and, frequently, employer matching of contributions. Under the program, workers can choose to deposit a percentage of their before-tax pay each month in investments such as mutual funds, guaranteed investment contracts or their employer's stock. These contributions are deducted automatically from the worker's paycheck. Earnings and contributions are taxed only when assets are withdrawn at retirement. In the interim, earnings compound at the pre-tax rate. Furthermore, most employers match all or part of employee contributions, yielding an even higher rate of return.

Not all workers are eligible, however. Workers are only eligible for the 401(k) program if their employer decides to offer a plan. In fact, employers determine almost all details of the program structure, including which investments are available, what matching rate will be provided, and whether workers can borrow against their $401(\mathrm{k})$ balances.

Although households have invested large sums of money in their 401(k) accounts, these balances may not represent new saving. Households may simply have transferred existing assets to these accounts or invested money in 401(k)s that they would have saved even without the program. If so, the government is subsidizing saving that would have occurred in the absence of the 401(k) program.

\footnotetext{
${ }^{1}$ Its use did not become widespread until the IRS issued clarifying regulations in 1981. 401(k) plans are available only to workers in for-profit firms. Workers in non-profits are eligible for 403(b)s, and state and local government employees participate in 457 plans. Government plans are often called "thrift" plans. All these programs have similar provisions and features. The empirical analysis in this paper classifies $401(\mathrm{k}), 403(\mathrm{~b})$, and thrift plans as 401(k)s.

${ }^{2}$ U.S. Department of Labor (2001), Table D-3. This figure is an underestimate, since it excludes public-sector plans.
} 
To examine whether the $401(\mathrm{k})$ program increases private saving, I compare the changes in wealth over time of 401(k) eligible and ineligible workers. ${ }^{3}$ If 401(k)s raise saving, I expect that the wealth of eligible households will grow faster over time than the wealth of ineligible households. The identifying assumption of this test is that in the absence of the 401(k) program, eligible and ineligible households would have equivalent wealth accumulation patterns after controlling for observable characteristics that affect saving, such as age, education and marital status. Variants of this test were originally laid out in the work of Poterba, Venti and Wise (1995, 1996a, 1996b), Engen, Gale and Scholz (1994, 1996) and Engen and Gale (1997, 2000).

Poterba, Venti and Wise conclude that most 401(k) contributions represent new saving, while Engen and Gale / Engen, Gale and Scholz find that 401(k) contributions are largely offset by reductions in other assets. ${ }^{4}$

I carry out these comparisons using data from the 1989, 1992, 1995 and 1998 Surveys of Consumer Finances. The SCF is substantially more recent than the data used in other 401(k) research and is generally considered the highest quality wealth data available. ${ }^{5}$ It also has several unique features that allow me to address some limitations of the existing 401(k) literature.

First, I use an extensive battery of subjective questions plausibly related to household saving habits and preferences to control for differences in saving taste between eligible and ineligible households. Households with a high taste for saving may gravitate towards the 401(k) program, either by seeking out employers that offer the program or by pressuring their current employer to offer a plan. An unobserved eligible-ineligible difference in saving taste can falsely suggest that the 401(k) program raises saving. Previous 401(k) research has discussed this selection issue in depth, but has lacked a direct method to assess its importance. In this paper, I document that adjusting for differences in saving taste decreases the estimated effect of $401(\mathrm{k}) \mathrm{s}$ on saving.

Second, I construct comprehensive measures of wealth from the detailed data available on the SCF. Engen and Gale (1997) emphasize that households can substitute between 401(k)s and any asset or liability. However, the wealth measures used in previous papers do not capture

\footnotetext{
${ }^{3} 401(\mathrm{k}) \mathrm{s}$ may increase private saving but not national saving. 401(k) contributions decrease tax revenue, which in turn decreases public saving.

${ }^{4}$ See Hubbard and Skinner (1996) and Engen and Gale (2000) for reviews of this literature.
} 
several possible margins of substitution, including many real asset categories. I find weak evidence that eligible households fund their 401(k) accounts by decreasing their holdings of real assets, suggesting that narrow measures of wealth, such as net financial assets, may inaccurately suggest that $401(\mathrm{k})$ increase saving.

Another possible margin of substitution is firm-level substitution of 401(k) plans for other retirement plans. From 1984 to 1996, the percentage of the workforce covered by a defined benefit pension fell by twelve percentage points, while the percentage participating in a 401(k) increased by twenty-one percentage points. ${ }^{6}$ If workers are receiving 401(k) benefits in lieu of retirement benefits that they would have otherwise received, the 401(k) program is not increasing wealth. ${ }^{7}$ However, I find little evidence that firm-level pension substitution is biasing the results. In fact, eligible households have more wealth in non-401(k) pension plans than ineligible households. Furthermore, adding these non-401(k) pension benefits to the wealth measure has little to no effect on the change in eligible wealth, relative to ineligible wealth, over time.

Finally, I address two technical issues that may overstate the estimated effect of $401(\mathrm{k}) \mathrm{s}$ on saving. As is standard in the literature, I compare the wealth of eligible and ineligible households using median regression. I show that adjusting the median regression standard errors for heteroskedasticity and for the inherent measurement uncertainty in wealth data substantially increases the standard errors, casting doubt on previous results reported as being statistically significant.

In addition, I use an inverse hyperbolic sine transformation to measure change in wealth over time in percentages rather than levels. If eligible households start out with more wealth than ineligible households, yet increase their saving at the same percentage rate, a "levels" specification will indicate that the $401(\mathrm{k})$ program has increased saving, while a percentage change specification will not. I estimate the parameters of the inverse hyperbolic sine transformation using maximum likelihood, thus exploiting the equivalence of median regression and maximum likelihood when the error term has a LaPlace distribution. This methodology extends the work of

\footnotetext{
${ }^{5}$ Engen and Gale (2000), for example, use the 1987 and 1991 Surveys of Income and Program Participation, while Engelhardt (2000) uses the 1992 Health and Retirement Study.

${ }^{6}$ Tabulation based on U.S. Department of Labor (2000), Tables E4 and E23.

${ }^{7}$ Engelhardt (2000) provides one of the first direct examinations of this hypothesis.
} 
Burbidge, Magee and Robb (1988) to the case of median regression. I demonstrate that incorporating this modification decreases the estimated effect of $401(\mathrm{k}) \mathrm{s}$ on saving.

After implementing these adjustments, I find that the 401(k) program had a small, if any, effect on saving over the 1989-1998 period. Although real median 401(k) balances grew from $\$ 4,000$ in 1989 to $\$ 11,000$ in 1998 , the wealth of eligible households did not grow relative to the wealth of ineligible households, either in the aggregate or within income categories, even when non-401(k) retirement assets are added to the wealth measure. Differences in saving taste and initial wealth, rather than the saving incentives of the 401(k) program, appear to underlie the large account balances that eligible households accumulated over the 1990s.

\section{SURVEY OF CONSUMER FINANCES}

The Survey of Consumer Finances has been conducted by the Federal Reserve every three years since 1983. The survey is designed to measure household wealth and financial decisions. It contains extensive information on all aspects of the household balance sheet and is generally considered the highest-quality wealth data available. The designs of the 1989, 1992, 1995 and 1998 surveys are almost identical, while the earlier surveys are somewhat different.

Curtin, Juster and Morgan (1989) compare wealth data from the Survey of Consumer Finances, the Survey of Income and Program Participation (SIPP), and the Panel Study of Income Dynamics (PSID), and conclude that "for studies in which saving or net worth itself is the major object of interest, the SCF design has more of the right characteristics than either the PSID or the SIPP" (p. 545). The authors note that although the SCF has generally worse response rates and potential nonresponse bias than the other two surveys, it has more detailed information about wealth holdings, better distributional characteristics, less item nonresponse, and fewer imputed variables. It also provides the most accurate match to national wealth totals. Sabelhaus and Ayotte (1998) use the SCF to study the effect of 401(k)s on saving, but all other research has used different sources. ${ }^{8}$

Using the detailed information on the SCF, I construct several measures of wealth that may be more comprehensive and accurate than measures used in previous studies. Net financial assets, for example, includes saving, checking and money market accounts, certificates of deposit,

\footnotetext{
${ }^{8}$ Bernheim and Scholz (1995), Juster and Kuester (1991) and Kennickell and Starr-McCluer (1994) also attest to the high quality of the SCF wealth data.
} 
stocks, bonds, mutual funds, 401(k)s, IRAs and the cash value of whole life insurance policies, minus credit card loans and other consumer loans except home equity, mortgage, and car loans. Net worth includes net financial assets as well as the value of cars, houses, investment real estate, businesses and other miscellaneous assets, minus loans against these physical assets. ${ }^{9}$

401(k) Eligibility. The SCF does not ask households directly if they are eligible for the 401(k) program. An accurate measure of 401(k) eligibility can be constructed from the 1995 and 1998 surveys, but the measure based on the 1989 and 1992 surveys misclassifies approximately nine percent of observations. Most notably, the 1989-1992 measure classifies all households who are participating in one retirement plan, and who are also eligible for — but not participating in the 401(k) program, as 401(k) ineligible. As shown later in the paper, the mismeasurement in the 1989-1992 definition does not have a large effect on any specification except those that include pension wealth in the wealth measure. Appendix A provides the SCF question structure and the construction of the $401(\mathrm{k})$ eligibility measures. ${ }^{10}$

Saving taste variables. As noted in the literature, if households with a high taste for saving seek out employers that offer the program, a positive correlation between 401 (k) eligibility and saving may reflect a difference in saving taste rather than an effect of the 401(k) program. ${ }^{11}$ I attempt to adjust for this potential selection issue by constructing multiple measures of saving taste that capture aspects of the respondents' risk aversion, discount rate, and expectations.

First, the SCF asks respondents what time period is most important for saving and spending purposes. I create a dummy variable for "short time horizon" if a household responds "next few months" or "next year," for "medium time horizon" if a household responds "next few years" or "next five to ten years," and for "long time horizon" if a household responds "longer than ten years."

Second, the SCF asks about the household's primary reason for saving. I create dummy variables for the three most frequently cited answers: retirement, children's education and emergencies. The SCF also asks if a household has any major foreseeable expenses in the next

\footnotetext{
${ }^{9}$ I use the standard Survey of Consumer Finances definition of net worth as found in the 1989, 1992, 1995 and 1998 SCF codebooks.

${ }^{10}$ The 1992 Health and Retirement Survey 401(k) question structure is identical to the 1992 SCF question structure. (See Engelhardt, 2000). The SIPP asks households directly if they are eligible for the 401(k) program but only has data through 1991.
} 
five to ten years. If the respondent answers yes, the SCF asks what those expenses are. I create dummy variables for anticipated health expenses and children's educational expenses.

Third, the SCF asks: over the next five years, do you expect the U.S. economy as a whole to perform better or worse than it has over the past five years? I set a dummy variable equal to one for households who expect the economy to worsen. A fourth set of questions ask how important it is to the household to leave a bequest. I create dummy variables for "very important" and "somewhat important." I also create a dummy variable for households who expect to receive a bequest. Fifth, the survey asks households about the degree of risk that they are willing to take with their investments. Following the coding in the SCF codebook, I create dummy variables for "take very high investment risks," "take above average risks," "take average risks" and "take no risks."

Table 1 displays the means of these variables by eligibility status, weighted by the SCF sampling weights. Eligibles and ineligibles clearly differ across some dimensions of saving taste. Eligibles are more likely to name retirement as their primary reason for saving. They are more likely to anticipate significant expenses in the next five to ten years, especially expenditures for children's education. Ineligible households, in contrast, are more likely to anticipate future health expenditures. In addition, eligible households place a higher value on farther-off time periods than do ineligibles. They tolerate more risk in their investments and are more likely to expect a bequest. These differences are statistically significant in most of the four years.

As noted earlier, eligible households are wealthier and more educated than their ineligible counterparts. The saving taste differences may reflect only these underlying demographic differences. To check this possibility, I calculated the sample means conditional on three separate distributions: age, education, and income. Even within each of these subgroups, eligible households appear to have higher tastes for saving, as indicated by these subjective responses, than ineligible households, suggesting that demographic differences alone may not explain the correlation between eligibility and saving taste. Table 2 displays these eligible - ineligible differences for 1995 conditional on income. Within the income subgroups, as within the age and education subgroups, the majority of these differences are statistically significant.

\footnotetext{
${ }^{11}$ See, for example, discussions in Poterba, Venti and Wise (1995, 1996a, 1996b), Engen, Gale and Scholz (1994, 1996) and Engen and Gale (1997, 2000).
} 
These variables, however, may reflect an effect of the $401(\mathrm{k})$ program as well as exogenous differences in saving taste. For example, under federal regulations, firms that offer the 401(k) program must document that both low-income and high-income workers are benefiting from the program. Firms may attempt to increase the participation of low-income workers by offering educational materials and seminars that tout the advantages of saving for retirement. In addition, workers may interpret their employer's provision of a retirement plan as a signal that saving for retirement is important, and increase their saving accordingly. If these aspects of the program affect a worker's saving habits and preferences, the saving taste variables may capture an effect of the 401(k) program as well as exogenous differences between eligible and ineligible households. In the empirical analysis, I test the sensitivity of the results to excluding saving measures most likely to be influenced by 401(k) eligibility.

\section{SPECIFICATION}

I compare the wealth of eligible and ineligible households using median regression, which minimizes the sum of absolute deviations and yields conditional medians as predicted values. Since it is not affected by outlier data points, it is a useful tool for wealth data, which often take on extreme values. ${ }^{12}$ The primary specification is:

$$
\begin{aligned}
Y=\theta^{*} \text { elig } & +\lambda_{92} * \text { elig }^{*} \text { year }_{92}+\lambda_{95} * \text { elig }^{*} \text { year }_{95}+\lambda_{98} * \text { elig }^{*} \text { year }_{98} \\
& +\delta_{92} * \text { year }_{92}+\delta_{95} * \text { year }_{95}+\delta_{98} * \text { year }_{98}+\mathrm{X} \beta+\varepsilon
\end{aligned}
$$

where $\mathrm{Y}$ is a measure of wealth, year ${ }_{92}$, year $_{95}$, year $_{98}$ and eligibility are dummy variables, $\mathrm{X}$ is a matrix of explanatory variables, and the median of $\varepsilon$, conditional on the explanatory variables, is zero. Following Engen and Gale (2000), who argue that 401(k) eligibility should have different effects across income groups, I also interact eligibility with income categories in some specifications.

The explanatory variables include age, education, income, marital status, family size, presence of two earners, race, industry, and defined benefit plan coverage. Income includes wages, investment income, welfare, child support, rental income and retirement payments. Industry is comprised of seven highly aggregated categories defined by the SCF. These variables 
are summarized by eligibility status in Table 3. As is apparent from the table, eligible households are quite different from ineligible households: they are wealthier, more educated, and more likely to be white than their ineligible counterparts. They are also more likely to be married and to have two working spouses, perhaps because two-earner households are more likely to have at least one 401(k) eligible spouse.

If $401(\mathrm{k}) \mathrm{s}$ increase saving, $\lambda_{92}, \lambda_{95}$ and $\lambda_{98}$ should be positive and $\lambda_{98}>\lambda_{95}>\lambda_{92}$, indicating that the wealth of eligible households grows faster over time than the wealth of ineligible households. This hypothesis relies on the identifying assumption that, in the absence of the 401(k) program, eligible and ineligible households would have equivalent wealth accumulation patterns after controlling on observable characteristics.

I create two samples from the pooled 1989, 1992, 1995 and 1998 SCF cross-sections. Each sample follows a broad cohort of workers. The first sample, using data from the 1989-1998 SCFs, contains households in which the head was 21-55 years old in 1989 (and hence 30-64 in 1998). The second, using data from the 1995 and 1998 SCFs, contains households in which the head was 21-61 in 1995. The second sample takes advantage of the more accurate definition of 401(k) eligibility made possible by the change in the SCF question structure in $1995 .{ }^{13}$

In both samples, I keep only households in which at least one spouse is working but neither spouse is self-employed. Since the $401(\mathrm{k})$ program is a work-based program, individuals who are not in the labor force cannot be eligible for the 401(k) program. Self-employed workers are not eligible for 401(k) plans, and often save differently from other workers as well. I inflate all income and wealth measures to 1998 dollars using the CPI-U.

The percent of the sample eligible for a 401(k) increased from 33 percent in 1989 to 55 percent in 1998. Given this dramatic increase in eligibility, a sizeable fraction of the sample in each year was not eligible earlier. Nonetheless, each cross-section has more exposure to the 401(k) program than its predecessor. For 401(k) eligible households in the 1989-1998 sample, the median length of participation increased from 2 years in 1989 to 5 years in 1998, while the mean rose from 4 years in 1989 to 6.2 years in 1998. Similarly, median 401(k) balances,

\footnotetext{
${ }^{12}$ Median regression is the standard tool in the literature, used, for example, by Poterba, Venti and Wise (1995, 1996a, 1996b), Engen, Gale and Scholz $(1994,1996)$, Engen and Gale $(1997,2000)$ and Engelhardt (2000).

${ }^{13}$ See Appendix A for the SCF 401(k) question structure.
} 
expressed in 1998 dollars, increased from $\$ 3,938$ in 1989 to $\$ 11,000$ in 1998 , while mean balances rose from $\$ 18,773$ to $\$ 38,292 .^{14}$

In addition, despite the influx of 401(k) eligible households, the characteristics of eligible and ineligible households have remained constant. Although these groups differ in their demographic characteristics and their tastes for saving, these characteristics do not change within either group over time. These findings are consistent with Engen and Gale (2000), who conclude that there is little evidence that the characteristics of eligible and ineligible households changed fundamentally over time.

Standard errors. I adjust the standard errors for two issues common to wealth data: heteroskedasticity and missing values. In the presence of heteroskedasticity, the textbook standard error formula for median regression produces estimates that can be substantially smaller than the true standard errors (Rogers, 1992). In the regressions in this paper, regression residuals are generally larger for high-income households than low-income households.

One obvious way to adjust for heteroskedasticity - bootstrapping - is complicated by the SCF sampling scheme. The SCF samples households on the basis of wealth, and in particular, oversamples wealthy households because they hold both a greater quantity and a greater variety of assets. When a variable, such as net worth, is both the stratification variable and the dependent variable in an analysis, the median regression estimator is not consistent because a crucial identifying assumption $-\operatorname{med}(\varepsilon \mid \mathrm{x})=0-$ does not hold. ${ }^{15}$ I address this selection issue by weighting the median regression with sampling weights that reflect each household's probability of being included in the sample. If these sampling weights represent the underlying population probabilities accurately, the median regression estimator will be consistent.

In addition, the SCF features a stratified, clustered sampling design. Since it is not a random sample, it is not appropriate to use a simple bootstrapping scheme in which each observation has a $1 / \mathrm{n}$ probability of selection, where $n$ is the sample size. In anticipation of this difficulty, the SCF includes a file of 1,000 bootstrap samples drawn in accordance with the SCF stratified sampling scheme. The SCF calculates a distinct vector of weights for each bootstrap

\footnotetext{
${ }^{14}$ Balances are measured over 401(k) eligible, rather than 401(k) participating, households for comparison purposes with the median regression specification.

${ }^{15}$ Holt et al. (1980) and Nathan and Holt (1980) make this argument in more detail for ordinary least squares.
} 
sample, using the algorithm that creates the weights for the main data set. I use these samples and the accompanying weights to calculate bootstrapped standard errors.

The SCF also provides methods for incorporating the uncertainty associated with missing values into the standard errors. Missing values are particularly a problem with wealth data: households may be reluctant to reveal their holdings of certain assets, or the assets may be hard to value. For example, 27 percent of households in the 1995 SCF with business assets reported that they did not know their value (Montalto and Sung, 1996).

In the SCF, missing data are imputed five times by drawing from the estimated conditional distribution of the variable. This technique, called repeated-imputation inference (RII), has several advantages over other methods of handling missing values. RII limits nonresponse bias by incorporating known reasons for nonresponse into the imputation procedure. Since RII includes all available information, it produces more efficient estimates than other methods. RII also explicitly incorporates the imputation uncertainty. ${ }^{16}$ Most previous 401(k) research has used the SIPP, which imputes missing data with a hot deck method. An expert panel convened by the Committee on National Statistics criticized the SIPP imputation procedure, noting that "the current cross-sectional imputation system for SIPP is very inflexible and is known to be less than optimal in some respects" and does "not adequately reproduce known relationships between income, assets and program participation.,"1718

Repeated-imputation inference generates five complete replicates of the data set, with five potentially different values for any data points that were originally missing. The regressions are run separately over each replicate. The final point estimates are the average of the five sets of coefficients. Usually, the standard errors are the average of the five sets of standard errors, with an additional adjustment for the imputation variance. I use data from just the first replicate to estimate standard errors, since the SCF provides the necessary bootstrapping variables for the first replicate only. The adjustment for imputation uncertainty, however, is based on all five replicates. Appendix B provides more detail and the formulas used to estimate standard errors.

\footnotetext{
${ }^{16}$ See Little (1992), Montalto and Sung (1996) and Kennickell (1998) for more information.

${ }^{17}$ Citro and Kalton (1993), pp. 150 and 211
} 


\section{RESULTS}

Table 4 shows the changes in levels of eligible and ineligible wealth over the 1989-1998 time period, controlling for observed characteristics. The first specification, shown in the left half of the table, does not incorporate the subjective saving taste variables. The table suggests that eligible households had \$3,631 more financial assets than ineligible households in 1989, and that these assets grew by $\$ 11,271$ more than the financial assets of ineligible households over the 1989-1998 time period. Financial assets excluding 401(k) wealth are essentially zero at all time periods, suggesting that eligible households were not substituting other financial assets for 401(k) wealth.

Eligible households also had $\$ 9,172$ more in net worth than ineligible households in 1989 , but their net worth grew by a statistically insignificant $\$ 4,912$ more over the 1989-1998 period, suggesting that some of the growth in financial assets was offset by reductions in real assets. The negative, albeit insignificant, coefficients on changes in net worth excluding 401(k)s, changes in real assets, and changes in home equity also indicate possible substitution between $401(\mathrm{k})$ wealth and real assets. The overall pattern of coefficients in this specification suggests that $401(\mathrm{k}) \mathrm{s}$ increase saving, in part at the expense of investment in real assets. However, the insignificant change-in-net-worth coefficient could also indicate that 401(k)s have no effect on saving.

Saving taste variables. Adding controls for subjective differences in saving taste, as shown in the right half of Table 4, weakens the relationship between 401(k) eligibility and saving. When saving taste variables are added to the specification, the increase in the net financial assets of eligible households over the 1989-1998 period -- relative to the change in net financial assets of ineligible households -- falls from $\$ 11,271$ to $\$ 7,837$ and is no longer statistically significant. For the other measures - net financial assets excluding 401(k)s, net worth, net worth excluding 401(k)s, and home equity - the change in the wealth of eligible households, relative to the change in the wealth of ineligible households, also decreases substantially. The coefficients suggest, for example, that net worth excluding 401(k) wealth decreased $\$ 6,363$ more for eligible than ineligible households over the 1989-1998 period, an amount almost equivalent in magnitude to the

\footnotetext{
${ }^{18}$ Comparisons of the SIPP with the 1983 SCF suggest that imputation is also more prevalent in the SIPP. See Curtin, Juster and Morgan (1989). No comparisons have been done with the more recent releases of the SCF used in this paper.
} 
increase in net financial assets. The fall in net worth may be driven by decreases in home equity, which declined by a statistically significant $\$ 3,510$ over the entire 1989-1998 period.

As mentioned previously, the saving taste variables may capture an effect of the 401(k) program as well as exogeneous differences between eligible and ineligible households. To gauge the sensitivity of the results to the different measures of saving taste, I exclude each measure in turn from the saving taste specification. Excluding the "reason for saving" variables (which include "retirement" as a response) and the "tolerance for risk" variables has the largest effect on the 1989-1998 eligibility interaction coefficient, increasing it from $\$ 7,837$ to $\$ 9,826$ and $\$ 8,396$, respectively. Excluding the other measures increases the coefficient by smaller amounts. As a point of comparison, recall that the coefficient is $\$ 11,271$ when all saving taste measures are excluded. These results suggest that the relationship between $401(\mathrm{k})$ eligibility and saving taste is not determined solely by any measure, although measures with a closer association to retirement saving appear to play a larger role.

The full set of coefficients from the Table 4 net financial assets specification, including the subjective saving taste measures, are presented in Appendix C. The coefficients follow sensible patterns: for example, wealth increases with income, education, age and the time horizon for saving. The coefficients are consistent across specifications; the full set of coefficients from other specifications are available upon request.

The inverse hyperbolic sine transformation. Although Table 4 suggests that 401(k) eligible households accumulated more net financial assets than ineligible households over the 1989-1998 period, there is an alternative way to view these numbers. As indicated by the sample statistics in Table 3, eligible and ineligible households differ dramatically in their wealth holdings. In 1998 , for example, the median net financial assets of eligible households were $\$ 26,472$, contrasted with a median of $\$ 1,940$ for ineligible households. Eligible households may have more wealth than ineligible households at a point in time because the specification does not control completely for underlying differences between the two groups. Examining the change in wealth within the group of eligible households, relative to the change for ineligible households, may control better for this unobserved heterogeneity. ${ }^{19}$

\footnotetext{
${ }^{19}$ Engen and Gale (2000) emphasize the over-time coefficient, rather than the "eligibility" coefficient, for these reasons. As in this paper, they find large and positive differences between the wealth of eligible and ineligible households at a point in time but not, in general, over time.
} 
However, when eligible households have more wealth than ineligible households, comparisons of changes within groups can also be misleading. If the wealth of the two groups grows at the same percentage rate, but eligible households begin with more wealth, the wealth of eligible households will increase in arithmetic terms relative to ineligible households. ${ }^{20}$ The traditional solution to this problem - a percentage change specification implemented by taking the natural logarithm of the dependent variable - is inappropriate because wealth measures often take on negative values. ${ }^{21}$ Twenty one percent of my sample, for example, has negative net financial assets.

An alternative transformation, the inverse hyperbolic sine (IHS), approximates the natural logarithm but is defined for positive and negative values of wealth. If $\theta$ is a scaling parameter and $x$ is a measure of wealth, the transformation is $\theta^{-1} \sinh ^{-1}(\theta x)=\theta^{-1} \ln \left(\theta x+\sqrt{ }\left(\theta^{2} x^{2}+1\right)\right) .^{22}$ Its derivative is $1 / \sqrt{ }\left(\theta^{2} x^{2}+1\right)$. If $x$ is large relative to $\theta$, this derivative approximates the derivative of the log; if $x$ is small relative to $\theta$, the derivative is approximately one. Linearity may be a more appealing assumption for small values of wealth: we may not want to treat a household whose wealth increases from $\$ 1$ to $\$ 2$ equivalently to a household whose wealth increases from $\$ 10,000$ to $\$ 20,000$.

If $\varepsilon$ has a LaPlace, or double exponential, distribution, my estimators $\beta$ and $\theta$ can be interpreted as maximum likelihood estimators. I estimate the optimal value of $\theta$ for each wealth measure by maximum likelihood, thus extending the work of Burbidge, Magee and Robb (1989) to the case of median regression. ${ }^{23}$ The IHS transformation includes the "levels" specification as a special case: as $\theta \rightarrow$ zero, $\operatorname{IHS}(x) \rightarrow x .^{24}$ For all wealth measures, a likelihood ratio test rejects

\footnotetext{
${ }^{20}$ This change-over-time in levels specification is common in the literature; see, for example, Engen and Gale (1997) and Sabelhaus and Ayotte (1998). Engen and Gale (2000) discuss the shortcomings of this specification.

${ }^{21}$ Engen and Gale (2000), using a technique outlined in Johnson, Kitamura and Neal (2000), apply the natural logarithm transformation after setting negative wealth values to 1 . If the conditional median is greater than zero, this recoding does not affect the coefficients. However, standard errors are affected in some cases. The technique changes the distribution of the residuals, and the analytical standard error formula depends on the distribution of the residuals at zero.

${ }^{22}$ If $x$ is large, $\ln \left(\theta x+\sqrt{ }\left(\theta^{2} x^{2}+1\right)\right) \approx \ln 2 \theta+\ln x$, which is simply a vertical displacement of the logarithm.

${ }^{23}$ The optimal values of $\theta$, assuming $\varepsilon$ has a LaPlace distribution, are 0.001 for net financial assets, net financial assets excluding 401(k)s, and home equity; 0.0007 for net real assets; 0.0003 for net financial assets plus pension wealth; and 0.0001 for net worth, net worth excluding $401(\mathrm{k}) \mathrm{s}$, and net worth including pension wealth. Under the assumption that $\varepsilon$ has a normal distribution, Burbidge, Magee and Robb find an optimal $\theta$ value of 0.0001 for net worth. Kennickell and Sunden (1997) also use a value of 0.0001 in their IHS transformation of net worth.

${ }^{24}$ See Burbidge, Magee and Robb (1988).
} 
the null hypothesis that the optimal $\theta$ equals zero, suggesting that the IHS specification is preferable to the levels specification.

Table 5 shows the effect of applying the IHS transformation to the wealth measure. Coefficients are displayed as marginal effects evaluated at the median level of the wealth measure in the sample. As in the levels specification, eligible households have significantly more financial assets in 1989 than ineligible households. However, contrary to the levels specification, their financial assets do not increase much over time relative to the growth of ineligible assets. In the saving taste specification, the 1989-1998 "over time" coefficient is only $\$ 1,451$ using the net financial assets measure, compared to $\$ 7,837$ in the comparable levels specification. This divergence suggests that the higher levels of net financial assets held by eligible households at the beginning of the period, were, in fact, inflating the over-time coefficients.

For the other wealth measures, the IHS specification, like the levels specification, suggests that 401(k) balances do not represent new saving. For example, in the saving taste IHS specification, net worth excluding $401(\mathrm{k})$ s decreased by $\$ 6,183$ for eligible households relative to ineligible households over the 1989-1998 time period. This point estimate is almost identical to the equivalent $\$ 6,343$ decrease in the levels specification. The levels and IHS results may be similar because eligible and ineligible wealth holdings, after conditioning on observed characteristics, are comparable for measures other than net financial assets. As before, the results suggests that workers may fund their 401(k) accounts by decreasing their home equity, although the relationship is weaker than in the levels specification.

Definition of $401(k)$ Eligibility. As noted earlier, it is difficult to identify precisely households in the 1989 and 1992 SCFs that were eligible for the 401(k) program but were not participating. To examine whether the results are biased by an inaccurate eligibility definition, I run the change-over-time test on the 1995 and 1998 SCF samples, using eligibility definitions based on both the 1989-1992 questions and the 1995-1998 questions. The specification, which uses the IHS transformation and the subjective saving taste variables, is presented in Table 6.

The table suggests that an inaccurate eligibility definition is not adding substantial bias. Both sets of results indicate that eligible wealth did not grow relative to ineligible wealth for any wealth measure over the 1995-1998 time period. Net financial assets excluding 401(k)s fell by $\$ 2,553$ (using the 1995-1998 definition) or by a statistically significant $\$ 4,213$ (using the 1989- 
1992 definition). Changes in home equity, however, did not play an important role over this three-year period.

Changes in Eligible Wealth within Income Groups. Engen and Gale (2000) note that the effect of 401(k) eligibility may vary with income. Saving rates, 401(k) participation rates and the tax savings from participating in a 401(k) all vary with income. In addition, they argue that comparing changes in eligible and ineligible wealth within income groups over time may control better for unobserved variables that might otherwise bias the analysis. Using the 1987 and 1991 SIPP, they conclude that 401(k) contributions represent net new saving for low-income households only. In the aggregate, they find substantial offset between 401(k)s and other assets.

Engen and Gale are undoubtedly correct that the 401(k) program has heterogeneous impacts and that eligible and ineligible households are more similar within income groups. ${ }^{25}$ However, their analysis has two limitations. First, as shown in Table 2 in this paper, eligible and ineligible households differ in their taste for saving even within income categories. As a result, their estimates are likely to be biased towards suggesting that 401(k)s increase saving. In addition, some of Engen and Gale's conclusions are based on analytical standard errors that substantially overstate statistical significance. ${ }^{26}$

An IHS specification incorporates more heterogeneity than a levels specification, since the marginal effect of eligibility depends on the level of wealth. Following Engen and Gale, I also allow the marginal effect of eligibility over time to depend on income. Table 7 shows changes in wealth for eligible households relative to ineligible households within income groups over the 1995-1998 time period. The specification uses the saving taste variables, the inverse hyperbolic sine transformation, and the 1995-1998 definition of eligibility, thus adjusting for three possible sources of bias. The IHS transformation is evaluated at the median level of each wealth measure within each income group. Since these results are based on smaller samples, they are noisier than the previous results.

The difference in wealth between eligible and ineligible households clearly increases with income. Using the IHS results, in 1995 eligible households with income between $\$ 10,000$ and $\$ 30,000$ had $\$ 1,176$ more net financial assets than equivalent ineligible households. Eligible

\footnotetext{
${ }^{25}$ Using propensity score methods, Benjamin (2001) also finds heterogeneous effects across households.

${ }^{26}$ Engen and Gale note in their paper that bootstrapped standard errors increase the standard errors of many of their findings and render them statistically insignificant.
} 
households with income between $\$ 50,000$ and $\$ 80,000$ had $\$ 18,611$ more net financial assets than ineligible households.

As with earlier results, however, almost no wealth measure increased for any income group over the 1995-1998 period. For example, net financial assets grew by only $\$ 1,910$ more for eligible than ineligible households in the $\$ 50,000-\$ 80,000$ income group. This near-zero growth is especially surprising given that median $401(\mathrm{k})$ balances in this income group grew by

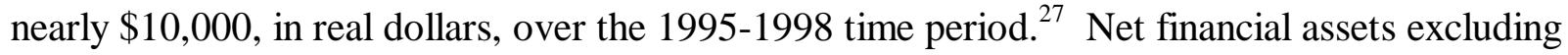
401(k) wealth decreased for all groups, and measures of net worth and home equity fell for all groups but eligible households in the $\$ 30,000-\$ 50,000$ income category. These results are inconsistent with Engen and Gale's finding that 401(k) eligibility raises the wealth of low-income households but are consistent with their overall conclusion that eligibility has little effect on aggregate saving.

Standard errors. Table 8 displays standard errors for the change-over-time coefficient for net financial assets, calculated via three different methods - the analytical formula, bootstrapping, and bootstrapping with an adjustment for imputation inference. The analytical formula is not robust to heteroskedasticity, which is an issue for a levels specification because the regression residuals increase with income. It is not surprising, then, that the bootstrapped standard errors are substantially larger than the analytical standard errors for high-income households. Using the analytical standard errors, the $\$ 6,262$ increase in wealth over the 1995 1998 time period for eligible households with income of $\$ 50,000-\$ 80,000$ is statistically significant at the ten percent level, and the $\$ 265,783$ decrease in wealth for households with income over $\$ 150,000$ is significant at the one percent level. Neither coefficient is significant using the bootstrapped standard errors.

The IHS transformation decreases the size of outliers and reduces heteroskedasticity substantially. Thus, as shown in Table 8, the analytical and bootstrapped standard errors are comparable in size for all income groups in the IHS specification. ${ }^{28}$ Specifications that use wealth levels, however, will yield misleading inference if heteroskedasticity is not taken into account. ${ }^{29}$

\footnotetext{
${ }^{27}$ See Table 3.

${ }^{28}$ This specification displays the coefficient rather than the marginal effect.

${ }^{29}$ All existing work in the 401(k) literature, with the exception of some specifications in Engen and Gale (2000), uses levels specifications.
} 
Adjusting for imputation uncertainty can also increase the standard errors substantially, underscoring the potentially large error associated with imputing missing values. For example, running the specification from Table 8 separately over each replicate yields five fairly different estimates for the "income $\$ 50,000$ to $\$ 80,000$ " eligibility*year=98 coefficient: $\$ 11,186, \$ 6,888$, $\$ 2,823, \$ 6,466$ and $\$ 4,075$. The $\$ 11,186$ value is statistically significant at the five percent level using the bootstrapped standard error and at the ten percent level using the bootstrapped and imputation-adjusted standard error. Standard errors that do not incorporate this uncertainty, such as those based on the SIPP or the Health and Retirement Study (HRS), may again yield misleading inference.

Pension wealth. Department of Labor Form 5500 data indicates that the number of 401(k) plans increased from 83,301 in 1989 to 230,808 in 1996. Much of this growth appears to have come at the expense of both traditional defined benefit plans and non-401(k) defined contributions plans. Defined benefit plans fell from 132,467 to 63,657 over this period, while the total number of defined contribution plans, including 401(k)s, grew from 598,889 to 632,566, an increase of only 33,677 plans. $^{30}$

The conversion of non-401(k) defined contribution plans to 401(k) plans has been welldocumented. $^{31}$ Whether firms explicitly convert defined benefit pensions to $401(\mathrm{k}) \mathrm{s}$ is less clear: Papke (1999) found that over the 1985-1992 period, one defined benefit plan was terminated for every three 401(k) plans that were created, but Ippolito and Thompson (2000) suggest that some of these terminated plans were actually subsumed into another plan through a corporate merger or other reorganization. ${ }^{32}$ Alternatively, firms may substitute between defined benefit and 401(k) plans by redirecting resources to a 401(k) plan while retaining the defined benefit plan. ${ }^{33}$ A final form of substitution is implicit: new firms that would have created defined benefit plans in the past may now institute 401(k) plans.

If 401(k) eligible households are receiving benefits in the form of a 401(k) that they used to receive via a defined benefit pension, the 401(k) program has not increased their wealth. To

\footnotetext{
${ }^{30}$ See Gale, Papke and VanDerhei (2000) for a good discussion of these trends.

${ }^{31}$ See Andrews (1992), Engen, Gale and Scholz (1996) and Gale, Papke and VanDerhei (2000).

${ }^{32}$ Papke, Peterson and Poterba (1996) is consistent with both views: out of a sample of 43 pension plan sponsors, 45 percent indicated that another pension plan was converted into a 401(k) between 1986 and 1990. However, only one of these plans was a defined-benefit plan.

${ }^{33}$ See Gale, Papke and VanDerhei (2000) for anecdotal evidence of this form of substitution.
} 
examine whether firm-level substitution inflates the effect of $401(\mathrm{k}) \mathrm{s}$ on wealth, I use the selfreported pension data on the SCF to construct a comprehensive measure of the present value of defined benefit and defined contribution plans from current and past jobs.

This measure is likely to be imprecise, for at least two reasons. First, any calculation of pension wealth relies on a series of arbitrary assumptions; the assumptions used in this paper are described in detail in Appendix A. Second, self-reported pension information is notoriously noisy. Researchers have used three data sets that include both employee-reported and employerreported data on pension coverage - the 1983 SCF (Mitchell,1988, and Gustman and Steinmeier, 1989), the 1989 SCF (Starr-McCluer and Sunden, 1999), and the 1992 HRS (Gustman and Steinmeier, 2000) - and have concluded that workers are not well-informed about many aspects of their pension coverage. Gustman and Steinmeier (2000), for example, find that only about half of all respondents can correctly identify whether their retirement plan is a defined benefit or defined contribution pension. In addition, although the means and medians of the distributions of employer- and employee-reported pension values match well, only about 40 percent of the pension values reported by employees agree, even roughly, with the corresponding values reported by their employer.

Table 9 examines the effect of adding pension wealth to the Table 7 specification. ${ }^{34}$ Including pension assets affects the eligibility and the eligibility*year=98 coefficients very differently. The eligibility coefficient, which measures the difference in wealth between eligible and ineligible households at a point in time, increases for every income group when pension assets are added to the net financial assets measure. For middle-income households, for example, the coefficient increases from $\$ 10,173$ to $\$ 20,132 .^{35}$

However, the eligibility*year $=98$ coefficient, which measures the change in wealth for eligible households relative to the change in wealth for ineligible households, barely changes for any income group. Using the same example, for middle-income households the coefficient increases from $\$-308$ to $\$ 765$.

\footnotetext{
${ }^{34}$ The net financial assets results are not identical to the results in Table 7 because I exclude a dummy for defined benefit plan participation from the right hand side.

${ }^{35}$ 401(k) eligible households are more likely than ineligible households to have defined benefit pension coverage, partially explaining the increase in the eligibility coefficient. In 1995, SCF tabulations suggest that 30 percent of 401(k) eligible households and 23 percent of ineligible households participated in a defined benefit pension.
} 
The stark discrepancy in the behavior of the two coefficients underscores the differences between eligible and ineligible households. Eligible households tend to have more wealth in all forms than ineligible households, including in non-401(k) pension benefits. Looking at changes within the group of eligible households may control better for this unobserved heterogeneity.

Using the Health and Retirement Survey and a self-reported definition of 401(k) eligibility, Engelhardt (2000) found that the difference in wealth between eligible and ineligible households in 1992 decreased substantially when he included pension assets in the wealth measure. ${ }^{36}$

Engelhardt's finding may stem, in part, from the HRS self-reported 401(k) eligibility definition, which is identical to the 1989 and 1992 SCF eligibility definition. As documented earlier, the 1989-1992 definition classifies all households who are participating in one retirement plan, and are eligible for - but not participating in - a 401(k), as 401(k) ineligible. This group represents 23 percent of all defined benefit participants and 26 percent of defined benefit pension wealth. When I repeat the Table 9 specification using the 1989-1992 definition of eligibility, the eligibility coefficient in the "net financial and pension assets" specification falls substantially, from $\$ 20,132$ to $\$ 6,199$ in the middle income group and from $\$ 32,959$ to $\$-10,187$ in the high income group.

\section{CONCLUSION}

Although the 401(k) balances of eligible households grew dramatically over the 19891998 period, the wealth of eligible households, relative to ineligible households, did not. This finding reflects several refinements in this paper relative to previous work. I control for differences in subjective measures of saving taste; use the inverse hyperbolic sine transformation, evaluated at the optimal parameters, to assess changes in wealth over time; and modify the inference for heteroskedasticity and imputation uncertainty. In addition, the analysis is based on the most recent and highest quality wealth data available.

After implementing these improvements, the growth in eligible wealth is essentially equal to the growth in ineligible wealth for all wealth measures. This finding holds true even within

Benjamin (2000) and Engen, Gale and Scholz (1994) also find higher DB coverage rates for 401(k) eligible households using the SIPP.

${ }^{36}$ The HRS contains employer-provided pension information for approximately half of Engelhardt's sample. Engelhardt includes results that use this subsample and the firm-reported definition of 401(k) eligibility. These results provide much weaker evidence than the self-reported data of a negative offset between 401(k) plans and defined benefit pensions. 
income groups, contrasting with the finding of Engen and Gale (2000) that 401(k) eligibility may raise the wealth of low-income groups. Adding pension assets to the wealth measure increases the difference between the wealth of eligible and ineligible households at a point in time, but again does not increase the wealth of eligible households, relative to ineligible households, over time. Instead, eligible households may fund their 401(k) accounts by decreasing their investments in real assets. These findings are more consistent with those of Engen and Gale /Engen, Gale and Scholz than those of Poterba, Venti and Wise.

The conclusions of this paper depend, in part, on the assumption that the subjective saving taste measures are only capturing exogeneous differences in saving taste. However, 401(k) eligibility may increase a worker's interest in saving for retirement. If the saving taste measures also reflect this effect, the results suggest that aspects of the program such as its educational component or the signal sent by employer provision of retirement benefits are important. Even taking this caveat into account, however, the results in this paper suggest that the 401(k) program has a relatively small effect on private saving. 


\section{REFERENCES}

Andrews, Emily S., "The Growth and Distribution of 401(k) Plans," in Trends in Pensions 1992, John A. Turner and Daniel J. Beller, eds., Washington, DC: U.S. Department of Labor, 1992.

Benjamin, Daniel, "Does 401(k) Eligibility Increase Saving? Evidence from Propensity Score Subclassification," mimeo, London School of Economics, 2001.

Bernheim, B. Douglas and John Karl Scholz, "U.S. Household Saving in the 1980s: Evidence from the Surveys of Consumer Finance." University of Wisconsin Working Paper, November 1995.

Board of Trustees of the Federal Old-Age and Survivors Insurance and Disability Insurance Trust Funds. 1995 Annual Report.

Buchinsky, Moshe, "Estimating the Asymptotic Covariance Matrix for Quantile Regression Models: A Monte Carlo Study," Journal of Econometrics, 1995, 68(2), pp. 303-338.

Burbidge, John B., Lonnie Magee, and A. Leslie Robb, "Alternative Transformations to Handle Extreme Values of the Dependent Variable," Journal of the American Statistical Association, 83(401), March 1988, pages 123-27.

Center for Disease Control and Prevention, "United States Life Tables 1998," National Vital Statistics Report, 48(18), February 7, 2001.

Citro, Constance F. and Graham Kalton, The Future of the Survey of Income and Program Participation, Washington, DC: National Academy Press, 1993.

Curtin, Richard T., F. Thomas Juster and James N. Morgan, "Survey Estimates of Wealth: An Assessment of Quality," The Measurement of Saving, Investment, and Wealth, Robert E. Lipsey and Helen Stone Tice, eds., Chicago: University of Chicago Press (1989).

Efron, Bradley, and Robert Tibshirani, An Introduction to the Bootstrap, New York: Chapman and Hall, 1993.

Engelhardt, Gary, "Have 401(k) Raised Household Saving? Evidence from the Health and Retirement Survey," mimeo, Syracuse University, 2000.

Engen, Eric, and William Gale, "Debt, Taxes and the Effects of 401(k) Plans on Household Wealth Accumulation," mimeo, May 1997.

Engen, Eric and William Gale, "The Effects of 401(k) Plans on Household Wealth: Differences Across Earnings Groups," NBER Working Paper \#8032, December, 2000. 
Engen, Eric, William Gale and John Karl Scholz, "Do Saving Incentives Work?," Brookings Papers on Economic Activity, 1994, 1, 85-151.

Engen, Eric, William Gale and John Karl Scholz, "The Illusory Effects of Saving Incentives on Saving," Journal of Economic Perspectives, Fall 1996, 58, 113-138.

Gale, William, Leslie Papke and Jack Van Derhei, "The Shifting Structure of Private Pensions: Evidence, Causes, and Consequences," in William G. Gale, John B. Shoven, and Mark Warshawsky, eds., The Evolving Pension System: Trends, Effects and Proposals for Reform, Brookings Institution, forthcoming.

Gustman, Alan and Thomas Steinmeier, "An Analysis of Pension Benefit Formulas, Pension Wealth, and Incentives from Pensions," Research in Labor Economics, 1989, 10: 53-106.

Gustman, Alan and Thomas Steinmeier, "What People Don't Know about Their Pensions and Social Security,” Dartmouth College Working Paper 99-11, November 2000.

Holt, D., T. M. F. Smith and P. D. Winter, "Regression Analysis of Data from Complex Surveys," Journal of Royal Statistical Society A, 1980, 143, pp. 474-487.

Hubbard, R. Glenn, and Jonathan S. Skinner, "Assessing the Effectiveness of Saving Incentives," Journal of Economic Perspectives, 10(4), pp. 73-90, 1996.

Johnson, William, Yuichi Kitamura, and Derek Neal, "Evaluating a Simple Method for Estimating Black-White Gaps in Median Wages," American Economic Review, 90(2), May 2000, 339-343.

Juster, F. Thomas and Kathleen A. Kuester, "Differences in the Measurement of Wealth, Wealth Inequality, and Wealth Composition Obtained from Alternative Wealth Surveys," Review of Income and Wealth, 37(1), March 1991, 33-62.

Kennickell, Arthur B., "Multiple Imputations in the Survey of Consumer Finances," Federal Reserve Board of Governors Working Paper, September 1998.

Kennickell, Arthur B. and Martha Starr-McCluer, "Changes in Family Finances from 1989 to 1992: Evidence from the Survey of Consumer Finances," Federal Reserve Bulletin, October 1994, 861-882.

Kennickell, Arthur B. and Annika E. Sunden, "Pensions, Social Security, and the Distribution of Wealth.” Federal Reserve Board of Governors Working Paper, October 1997.

Khitatrakun, Surachai, Yuichi Kitamura, and John Karl Scholz, "Pensions and Wealth: New Evidence from the Health and Retirement Study," University of Wisconsin Economics Department Working Paper, December 2000. 
Little, Roderick J.A., "Regression with Missing X's: A Review," Journal of the American Statistical Association, December 1992, 87(420), pp. 1227-1237.

Mitchell, Olivia, "Worker Knowledge of Pension Provisions," Journal of Labor Economics, 1988, 6(1), pp. 28-39.

Montalto, C. P. and Sung, J. "Multiple Imputation in the 1992 Survey of Consumer Finances." Financial Counseling and Planning, 1996, 7, 133-146.

Nathan, G. and D. Holt. "The Effect of Survey Design on Regression Analysis." Journal of Royal Statistical Society B, 1980, 42(3), pp. 377-386.

Papke, Leslie E., "Are 401(k) Plans Replacing Other Employer-Provided Pensions? Evidence from Panel Data," Journal of Human Resources, 1999, 34:346-368.

Papke, Leslie E., Mitchell Peterson, and James M. Poterba, "Do 401(k) Plans Replace Other Employer-Provided Pensions?," in David A. Wise, ed, Advances in the Economics of Aging, Chicago: University of Chicago Press, 1996.

Peticolas, Robert W. and Thomas L. Steinmeier, "Pension Present Value Database (Level 1)", Institute for Social Research, University of Michigan, Ann Arbor, MI, http://www.umich.edu/ hrswww/center/rescont2.html, 1999.

Poterba, James, Steven Venti and David Wise, "Do 401(k) Contributions Crowd Out Other Personal Saving?," Journal of Public Economics, September 1995, 58, 1-32.

Poterba, James, Steven Venti and David Wise, "How Retirement Saving Programs Increase Saving", Journal of Economic Perspectives, Fall 1996, 58, 91-112.

Poterba, James, Steven Venti and David Wise, "Personal Retirement Saving Programs and Asset Accumulation: Reconciling the Evidence.” NBER Working Paper No. 5599, May 1996.

Rogers, William, sg11:“Quantile Regression Standard Errors.” Stata Technical Bulletin, 1992, 9, p. 16-19. Reprinted in Stata Technical Bulletin Reprints, vol. 2, pp.133-137.

Sabelhaus, John and Ken Ayotte, "The Effect of Tax-Deferred Saving Plans on Household Wealth Accumulation: Evidence from the Survey of Consumer Finances," Congressional Budget Office, mimeo, March 1998.

Starr-McCluer, Martha, and Annika Sunden, "Workers' Knowledge of their Pension Coverage: A Reevaluation," Federal Reserve Board of Governors Working Paper, January 1999.

STATA Corporation, STATA Reference Manual Release 6, College Station, TX: Stata Press, 1999. 
United States Department of Labor, Pension and Welfare Benefits Administration. "Abstract of 1996 Form 5500 Annual Reports," Private Pension Plan Bulletin No. 10, Winter 2001. Washington, DC: United States Government Printing Office, 2000. 


\section{APPENDIX A: \\ CONSTRUCTION OF 401(K) ELIGIBILITY AND PENSION WEALTH VARIABLES}

401(K) eligibility. The SCF does not ask households directly if they are eligible for a 401(k). Instead, this information has to be inferred from other questions on the survey. Furthermore, the questions are different in 1989 and 1992 than in 1995 and 1998.

This complex question structure is depicted in the accompanying flowchart. The striped boxes are questions asked only in 1995 and 1998. The two rows of boxes at the bottom of the chart show, by year, the eligibility classifications for four mutually-exclusive categories of workers. These categories are dictated by the SCF survey questions. Since two spouses may be in different categories, the sample sizes in the boxes do not sum to the total number of households.

A white box denotes an accurate classification: every worker in a white box marked "eligible" should, in fact, be 401(k) eligible. If a box is grey, the classification is not completely accurate. Some workers in a grey box marked "eligible" are 401(k) eligible, but others are not. A quick glance at the two rows reveals more grey boxes in the 1989 / 1992 row than in the 1995 /1998 row, underscoring the better data available in 1995 and 1998.

To make the definition of 401(k) eligibility clearer, I summarize the SCF retirement saving questions here, following the flowchart. First, the SCF asks workers if they are participating in a retirement program. If the answer is yes, it asks what program. Workers who are participating in a 401(k) are clearly 401(k) eligible.

Suppose a worker is participating only in a defined-benefit pension. Although this worker is not participating in a $401(\mathrm{k})$, she might be $401(\mathrm{k})$ eligible and choosing not to participate. In 1995 and 1998, the SCF asks workers who are participating in a plan other than a 401(k) if they are eligible for, but not participating in, "a tax-deferred savings, 401(k), or other such account plan." If a worker answers no, he is clearly ineligible for a 401(k). If a worker answers yes, she is almost surely 401(k) eligible.

In 1989 and 1992, the SCF does not ask workers who are participating in a plan other than a 401(k) whether they are eligible for, but not participating in, a tax-deferred savings or other type of account plan. Therefore, I categorize all workers who are participating in a program other than a 401(k) as 401(k) ineligible. 
Returning to the top of the flowchart: the SCF asks workers who are not participating in any program if they are eligible for any retirement program. Workers who say no are clearly ineligible for a 401(k). Suppose a worker says yes. In 1995 and 1998, the SCF asks what program they are eligible for. In 1995, 77 percent of these workers are 401(k) eligible; in 1998, 80 percent are eligible. I classify them accordingly. In the two earlier years, the SCF does not ask what program workers are eligible for, so I categorize all workers who are eligible for a program but not participating as $401(\mathrm{k})$ eligible.

Although the 1995 and 1998 survey questions are more accurate, approximately 91 percent of households are still characterized correctly in the earlier years of the survey. Using the 1995 and 1998 data, for example, I compare the households deemed eligible under the 1989-1992 survey definition to the households deemed eligible under the more precise 1995-1998 definition. This comparison suggests that nine percent of households are mischaracterized under the 19891992 definition.

As further evidence that the measurement problem is not severe, Appendix Table A1 compares selected demographic and saving taste characteristics of eligible and ineligible households under the two definitions. Under the 1995-1998 definition, ineligible households are slightly younger, poorer, less educated and less wealthy than households deemed ineligible under the 1989-1992 definition. In general these differences are small, although differences in median wealth are somewhat larger. In 1998, for example, median net financial assets for ineligible households were \$1,940 under the 1989-1992 definition and \$1,218 under the 1995-1998 definition. The samples also differ substantially in the percentage covered by a defined-benefit pension because the 1995-1998 "eligible" definition, unlike the 1989-1992 definition, includes households that have a defined benefit pension but do not participate in a 401(k).

Pension wealth. Since pension wealth is the present value of a future benefit, any calculation involves a number of arbitrary assumptions. For defined contribution plans, which include 401(k)s as well as other account-style plans, I set the pension value equal to the current account balance. Most studies use this assumption, ${ }^{37}$ although a few include the present value of expected future employee and employer contributions to the plan. ${ }^{38}$

\footnotetext{
${ }^{37}$ See, e.g., Kennickell and Sunden (1997) for a study using the SCF, and Gustman and Steinmeier (2000) for a study using the HRS.

${ }^{38}$ See, e.g., Khitatrakun, Kitamura and Scholz (2000).
} 
For defined benefit plans, SCF respondents can state the expected benefit either as a fixed amount that they expect to receive each period (e.g., $\$ 400$ a month) or as a percentage of salary. If the respondent gives a fixed amount, I assume that the benefit is stated in the dollars of the expected year of retirement. ${ }^{39}$ If the respondent gives a percentage of salary, I assume that the respondent's real wages grow one percent annually until the expected retirement date.

I assume a discount rate of 6.3 percent and a future inflation rate of 4 percent. These assumptions, and the assumption of one percent real wage growth, are taken from the Social Security Administration's intermediate projections (Board of Trustees, 1995). ${ }^{40}$ Mortality probabilities are conditioned on age, gender and race and are taken from the appropriate year of the Center for Disease Control's National Vital Statistics Report (see, e.g., Center for Disease Control, 2001). I assume no spousal benefit and no cost-of-living adjustment. All assumptions used in calculating defined benefit pension wealth, except the source of the mortality probabilities, are identical to those in the "Self-Reported Pension Wealth" dataset based on the Health and Retirement Survey. ${ }^{41}$ Some other studies have based defined-benefit calculations on constructed earnings profiles rather than assuming a rate of wage growth. ${ }^{42}$

\footnotetext{
${ }^{39}$ Kennickell and Sunden (1997) also make this assumption.

${ }^{40}$ Peticolas and Steinmeier (1999) use these values as their baseline scenario when calculating the present values of pension wealth from employer-provided pension documentation.

${ }^{41}$ Documentation for this file, contributed by an anonymous researcher, can be found at http://www.umich.edu/ hrswww/center/

${ }^{42}$ Again, see Kennickell and Sunden (1997) and Khitatrakun, Kitamura and Scholz (2000).
} 


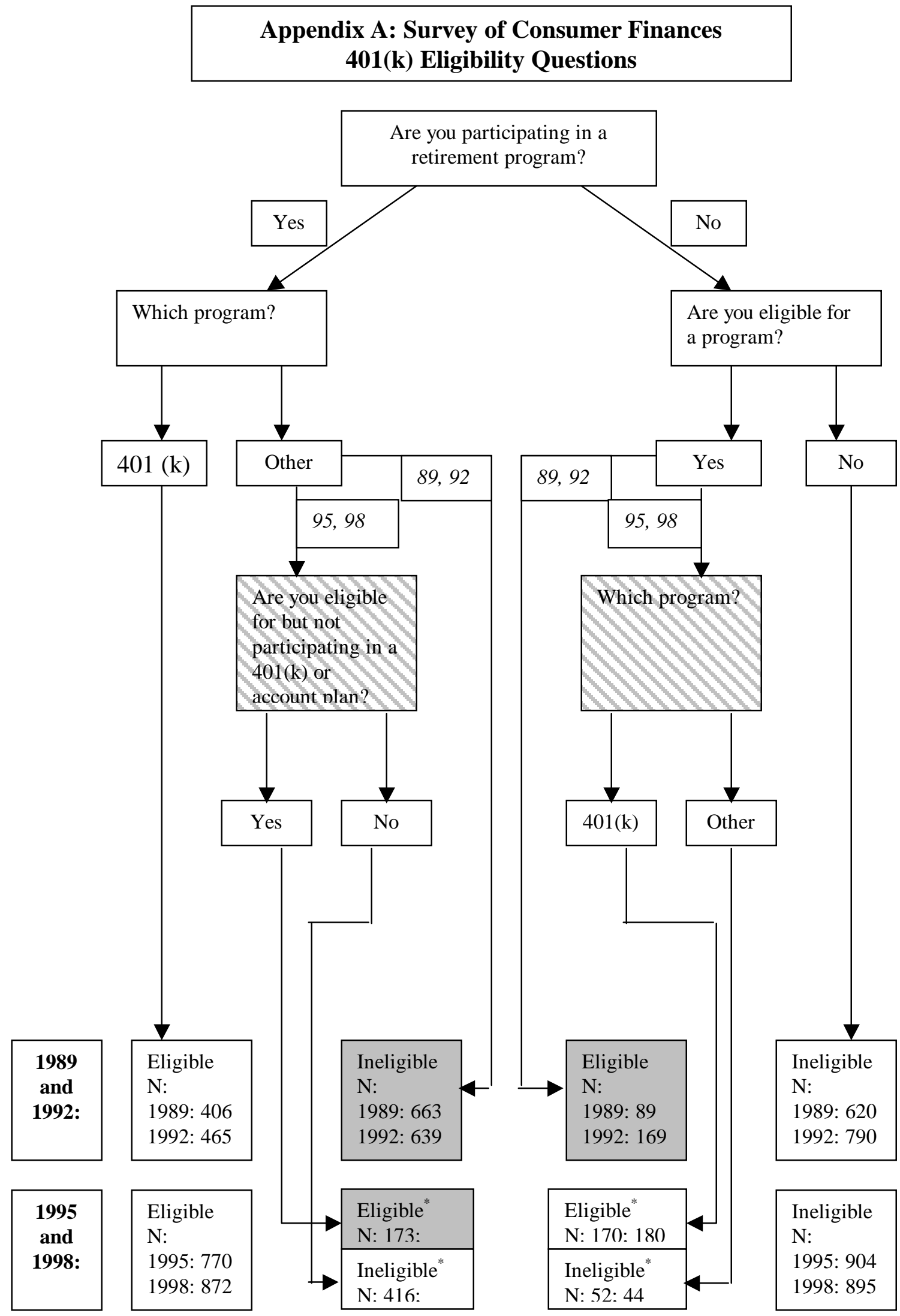




\section{APPENDIX TABLE A1: CHARACTERISTICS BY ELIGIBILITY DEFINITION}

\begin{tabular}{|c|c|c|c|c|c|c|c|c|}
\hline \multirow[b]{3}{*}{ Characteristic $(\%)$} & \multicolumn{4}{|c|}{1995} & \multicolumn{4}{|c|}{1998} \\
\hline & \multicolumn{2}{|c|}{ 1989-1992 definition } & \multicolumn{2}{|c|}{ 1995-1998 definition } & \multicolumn{2}{|c|}{ 1989-1992 definition } & \multicolumn{2}{|c|}{ 1995-1998 definition } \\
\hline & Eligible & Ineligible & Eligible & Ineligible & Eligible & Ineligible & Eligible & Ineligible \\
\hline \multicolumn{9}{|c|}{ Demographic characteristics } \\
\hline Age: $21-34$ & .34 & .33 & .32 & $.36^{* *}$ & .30 & $.33 *$ & .28 & $.36^{* * * *}$ \\
\hline Age: $35-44$ & .32 & .30 & .33 & $.28 * * *$ & .34 & $.30 * *$ & .34 & $.30 * * *$ \\
\hline Age: $45-54$ & .25 & .22 & .26 & $.20 * * *$ & .23 & .24 & .24 & .22 \\
\hline Age: $55-64$ & .09 & $.15 * * *$ & .09 & $.15^{* * *}$ & .13 & .13 & .14 & .13 \\
\hline Income: 1t $\$ 10 \mathrm{~K}$ & .03 & $.11 * * *$ & .02 & $.13 * * *$ & .03 & $.09 * * *$ & .03 & $.10 * * *$ \\
\hline Income: $\$ 10 \mathrm{~K}-\$ 30 \mathrm{~K}$ & .22 & $.37 * * *$ & .21 & $.40 * * *$ & .19 & $.35 * * *$ & .18 & $.38 * * *$ \\
\hline Income: $\$ 30 \mathrm{~K}-\$ 50 \mathrm{~K}$ & .29 & .27 & .30 & $.26^{* *}$ & .28 & .25 & .28 & $.25^{*}$ \\
\hline Income: $\$ 50 \mathrm{~K}-\$ 80 \mathrm{~K}$ & .27 & $.16 * * *$ & .27 & $.15 * * *$ & .29 & $.21 * * *$ & .29 & $.20 * * *$ \\
\hline Income: $\$ 80 \mathrm{~K}-\$ 150 \mathrm{~K}$ & .14 & $.07 * * *$ & .15 & $.05 * * *$ & .17 & $.08 * * *$ & .17 & $.06 * * *$ \\
\hline Income: $\$ 150 \mathrm{~K}+$ & .05 & $.02 * * *$ & .04 & $.02 * * *$ & .04 & $.02 * * *$ & .04 & $.02 * * *$ \\
\hline $\begin{array}{l}\text { Not a high school } \\
\text { grad }\end{array}$ & .08 & $.16 * * *$ & .08 & $.17 * * *$ & .09 & $.18 * * *$ & .09 & $.19 * * *$ \\
\hline High school graduate & .31 & .32 & .30 & .33 & .29 & .31 & .28 & $.32 *$ \\
\hline Some college & .25 & .27 & .25 & .27 & .28 & $.25^{*}$ & .28 & $.24 * * *$ \\
\hline College grad & .23 & $.15^{* * * *}$ & .23 & $.14^{* * * *}$ & .22 & $.15^{* * *}$ & .21 & $.15^{* * *}$ \\
\hline Post college & .13 & $.10^{* *}$ & .14 & $.09^{* * *}$ & .13 & .11 & .13 & $.10 * * *$ \\
\hline Not white & .21 & $.28 * * *$ & .21 & $.29 * * *$ & .20 & $.31 * * *$ & .19 & $.33^{* * *}$ \\
\hline DB plan participant & .26 & $.33 * * *$ & .37 & $.23 * * *$ & .26 & .28 & .34 & $.17 * * *$ \\
\hline $\begin{array}{l}\text { Net worth (median), } \\
\text { in } 1998 \$\end{array}$ & $\$ 68,729$ & $\$ 31,332$ & $\$ 65,658$ & $\$ 24,464$ & $\$ 76,385$ & $\$ 26,868$ & $\$ 80,012$ & $\$ 21,604$ \\
\hline $\begin{array}{l}\text { Net financial assets } \\
\text { (median), in } 1998 \text { \$ }\end{array}$ & $\$ 21,430$ & $\$ 1,284$ & $\$ 19,028$ & $\$ 966$ & $\$ 26,472$ & $\$ 1,940$ & $\$ 27,258$ & $\$ 1,218$ \\
\hline \multicolumn{9}{|l|}{ Saving taste variables } \\
\hline $\begin{array}{l}\text { Save for kid's } \\
\text { education }\end{array}$ & .08 & .08 & .08 & .08 & .08 & .09 & .07 & $.09 *$ \\
\hline Save for retirement & .32 & $.19 * * *$ & .31 & $.19 * * *$ & .45 & $.28 * * *$ & .45 & $.26 * * *$ \\
\hline Save for emergencies & .26 & .27 & .27 & .27 & .15 & .17 & .15 & .17 \\
\hline Most imp: short term & .29 & $.42 * * *$ & .29 & $.43 * * *$ & .27 & $.36 * * *$ & .26 & $.38 * * *$ \\
\hline $\begin{array}{l}\text { Most imp: medium } \\
\text { term }\end{array}$ & .53 & $.47 * * *$ & .53 & $.46 * * *$ & .53 & .50 & .54 & $.49 * * *$ \\
\hline Most imp: long term & .18 & $.11 * * *$ & .18 & $.10 * * *$ & .20 & $.14 * * *$ & .20 & $.14 * * *$ \\
\hline $\begin{array}{l}\text { Take very high invest } \\
\text { risks }\end{array}$ & .03 & .03 & .03 & .03 & .07 & $.04 * * *$ & .07 & $.04 * * *$ \\
\hline Take above avg risks & .21 & $.12 * * *$ & .20 & $.13 * * *$ & .27 & $.17 * * *$ & .27 & $.15^{* * *}$ \\
\hline Take average risks & .46 & $.39 * * *$ & .48 & $.36 * * *$ & .43 & $.37 * * *$ & .43 & $.38 * * *$ \\
\hline Take no risks & .29 & $.46 * * *$ & .29 & $.48 * * *$ & .23 & $.41 * * *$ & .23 & $.43 * * *$ \\
\hline
\end{tabular}

NOTES: The "1989-1992" definition is based on the 401(k) eligibility questions in the 1989 and 1992 SCFs; the "1995-1998" definition is based on the questions from the 1995 and 1998 SCFs. Standard errors are bootstrapped with 200 replications and are adjusted for imputation uncertainty.

*: difference of means statistically significant at $10 \%$ level; **: significant at $5 \%$ level; ***: significant at $1 \%$ level 


\section{APPENDIX B: \\ CALCULATING MEDIAN REGRESSION STANDARD ERRORS USING THE SURVEY OF CONSUMER FINANCES}

In this paper, four data-related factors complicate estimation of the median regression point estimates and standard errors. The first two of these factors, as listed below, affect all SCF analyses; the other two are specific to this paper. To recap these four issues:

(1) Missing values. Households either do not know the answer to some questions, or refuse to answer these questions.

Survey data issues. The SCF is not a random sample. The sample design includes clustering and stratification, both of which can affect standard errors. To protect respondents' identities, the SCF does not release these stratification and clustering variables. Therefore, I cannot use the textbook methods to adjust the standard errors for these sample design features.

(3) Heteroskedasticity. I regress wealth on income. In a levels of wealth specification, residuals for high-income households are larger than residuals for low-income households. In this situation, the textbook standard error formula for median regression produces estimates that can be substantially smaller than the true standard errors (Rogers 1992).

(4) Selection issues. The SCF is stratified on the dependent variable, net worth. Without dealing with this selection problem, the median regression estimator is not consistent.

I address these four problems as follows:

(1) The SCF data set contains five complete replicates of each observation. Missing data are imputed five times by drawing from the estimated conditional distribution of the variable; each of these estimates is contained in a different replicate. This technique is called repeated-imputation inference. It is discussed on the SCF web site: http://www.bog.frb.fed.us/pubs/oss/oss2/scfindex.html.

(2) In a separate file, the SCF provides 1,000 bootstrap samples for the first of the five replicates. These bootstrap samples are drawn in accordance with the SCF sampling design. Individual weights are calculated for each bootstrap sample using the SCF weighting algorithm. These bootstrap files are available for the 1989, 1992 and 1995 SCFs from their web site. By bootstrapping the standard errors, I incorporate the clustering and stratification features of the sample.

As in (2), I adjust for the heteroskedasticity by bootstrapping the standard errors.

(4) The SCF provides sample weights that reflect each household's probability of being included in the sample. I weight the median regression with these weights.

In repeated-imputation inference, the formulas for the coefficients and the standard errors are: 
$\mathrm{b}=\Sigma \mathrm{b}_{\mathrm{m}} / \mathrm{I}$

$\mathrm{v}^{2}=\mathrm{s}_{\mathrm{w}}^{2}+\left(1+\mathrm{I}^{-1}\right) \mathrm{s}_{\mathrm{b}}^{2}$

where $I$ is the number of replicates, $b_{m}$ is the is the estimate of $\beta$ from the $m$ th replicate, $\mathrm{v}_{\mathrm{m}}$ is the variance of $\mathrm{b}_{\mathrm{m}}, \mathrm{s}_{\mathrm{w}}{ }^{2}=\Sigma \mathrm{v}_{\mathrm{m}} / \mathrm{I}$ is the average variance within imputed data sets, $\mathrm{s}_{\mathrm{b}}^{2}=\Sigma\left(\mathrm{b}_{\mathrm{m}}-\mathrm{b}\right)^{2} /(\mathrm{I}-1)$ is the between-imputation variance and reflects uncertainty in the imputation process. (Notation and exposition taken from Little, 1992).

I adapt STATA's qreg algorithm to calculate the coefficients and standard errors. I calculate the weighted median regression coefficients and the between-imputation variance using all five replicates. Since the bootstrapped samples are available for the first replicate only, I use the variance from this replicate as the average variance within imputed data sets. Following conventional wisdom in the bootstrapping literature (Efron and Tibshirani, 1993), I use 200 bootstrapped draws. I use the pairwise (or "design matrix") bootstrap estimator, which yields the best results for median regression when heteroskedasticity is an issue (Buchinsky 1995). The code to perform these calculations is available from the author.

Note on STATA's “qreg” command: STATA's qreg command may still provide misleading inference even when the four problems discussed here are not an issue. Qreg estimates the regression standard errors using the textbook analytical standard error formula, which includes an estimate of the density of the residuals at zero. STATA computes this density in a manner similar to the nearestneighbor method. However, STATA's estimator includes the term $(\sqrt{ } \mathrm{n})-\mathrm{k}$ in the denominator. As a result, whenever $V_{\mathrm{n}}$ is close to $\mathrm{k}$, the estimates of the variance are near-zero. ${ }^{43}$

\footnotetext{
${ }^{43}$ See STATA Corporation, 1999, for more information.
} 
APPENDIX C:

Full Set of Coefficients from Table 4 Net Financial Assets Specification

\begin{tabular}{|c|c|c|c|}
\hline Net Financial Assets & Coefficient & Std. Error & t-stat \\
\hline Eligibility & 3,587 & 1,973 & 1.82 \\
\hline Eligibility*Year $=92$ & 1,446 & 1,439 & 1.00 \\
\hline Eligibility*Year $=95$ & 4,830 & 5,558 & 0.87 \\
\hline Eligibility*Year $=98$ & 7,837 & 6,753 & 1.16 \\
\hline Year $=92$ & 51 & 689 & 0.07 \\
\hline Year $=95$ & -408 & 3,064 & -0.13 \\
\hline Year $=98$ & 2,952 & 3,114 & 0.95 \\
\hline Income: $\$ 10 \mathrm{~K}-30 \mathrm{~K}$ & -664 & 795 & -0.84 \\
\hline Income: $\$ 30 \mathrm{~K}-50 \mathrm{~K}$ & 1,539 & 2,311 & 0.67 \\
\hline Income: $\$ 50 \mathrm{~K}-80 \mathrm{~K}$ & 10,864 & 4,916 & 2.21 \\
\hline Income: $\$ 80 \mathrm{~K}-\$ 150 \mathrm{~K}$ & 47,734 & 10,751 & 4.44 \\
\hline Income: greater than $\$ 150 \mathrm{~K}$ & 168,205 & 18,624 & 9.03 \\
\hline Age in 1989: $35-44$ & 3,693 & 826 & 4.47 \\
\hline Age in 1989: 45-54 & 9,329 & 1,518 & 6.14 \\
\hline High school graduate & 1,286 & 1,397 & 0.92 \\
\hline Some college & 1,852 & 3,057 & 0.61 \\
\hline College graduate & 2,698 & 3,296 & 0.82 \\
\hline Graduate school & 12,958 & 5,443 & 2.38 \\
\hline Divorced & $-2,155$ & 1,017 & -2.12 \\
\hline Married & -354 & 1,592 & -0.22 \\
\hline Two earners & $-2,823$ & 2,301 & -1.23 \\
\hline Family size & 123 & 168 & 0.74 \\
\hline Not white & $-1,286$ & 731 & -1.76 \\
\hline DB participant & 2,034 & 4,086 & 0.5 \\
\hline Reason: child's education & 1,116 & 1,100 & 1.01 \\
\hline Reason: retirement & 8,476 & 4,531 & 1.87 \\
\hline Reason: emergencies & 555 & 441 & 1.26 \\
\hline No foreseeable expenses & 607 & 1,445 & 0.42 \\
\hline Foresee child's education & 965 & 1,348 & 0.72 \\
\hline Foresee bad health & 517 & 2,645 & 0.2 \\
\hline Most imp. Horizon 1-10 yrs & 2,443 & 978 & 2.5 \\
\hline Most imp. Horizon: gt $10 \mathrm{yrs}$ & 3,604 & 1,256 & 2.87 \\
\hline Expect bequest & 1,370 & 2,054 & 0.67 \\
\hline Bequest very important & 387 & 796 & 0.49 \\
\hline Bequest somewhat important & -367 & 1,132 & -0.32 \\
\hline Take very high risks & 2,353 & 1,387 & 1.7 \\
\hline Take above average risks & 5,846 & 2,994 & 1.95 \\
\hline Take average risks & 2,714 & 735 & 3.69 \\
\hline Future economy bad & 257 & 507 & 0.51 \\
\hline Constant & $-8,335$ & 6,800 & -1.23 \\
\hline
\end{tabular}

NOTE: standard errors are bootstrapped with 200 replications and are adjusted for imputation uncertainty. See Appendix A for details. Industry dummies excluded from table. Uses the 1989-1992 definition of eligibility. 
TABLE 1: Weighted Means of Saving Characteristics by Eligibility

\begin{tabular}{|c|c|c|c|c|c|c|c|c|}
\hline \multirow[b]{2}{*}{ Variable } & \multicolumn{2}{|c|}{1989} & \multicolumn{2}{|c|}{1992} & \multicolumn{2}{|c|}{1995} & \multicolumn{2}{|c|}{1998} \\
\hline & Eligible & Ineligible & Eligible & Ineligible & Eligible & Ineligible & Eligible & Ineligible \\
\hline Save for kid's education & .08 & .07 & .08 & $.10 * *$ & .08 & .08 & .08 & .09 \\
\hline Save for retirement & .23 & $.17 * *$ & .26 & $.16^{* * *}$ & .32 & $.19^{* * *}$ & .45 & $.28 * * *$ \\
\hline Save for emergencies & .30 & .27 & .27 & .29 & .26 & .27 & .15 & .17 \\
\hline Foresee any expenses & .60 & .57 & .52 & .52 & .66 & $.62 * *$ & .61 & $.55^{* * *}$ \\
\hline Foresee kid's education & .40 & $.35 * * *$ & .36 & .33 & .25 & $.20 * * *$ & .25 & $.21 *$ \\
\hline Foresee health expenses & .06 & $.10 * *$ & .05 & .06 & .04 & $.05^{*}$ & .03 & $.05 * * *$ \\
\hline $\begin{array}{l}\text { Don't foresee any } \\
\text { expenses }\end{array}$ & .40 & .43 & .48 & .48 & .34 & $.38 * *$ & .39 & $.45^{* * *}$ \\
\hline Most imp: short term & .28 & $.43 * * *$ & .26 & $.38 * * *$ & .29 & $.42 * * *$ & .27 & $.36 * * *$ \\
\hline Most imp: medium term & .51 & $.45^{*}$ & .54 & $.46^{* * * *}$ & .53 & $.47 * * *$ & .53 & .50 \\
\hline Most imp: long term & .21 & $.12 * * *$ & .20 & $.17 *$ & .18 & $.11^{* * *}$ & .20 & $.14 * * *$ \\
\hline Bequest very important & .21 & .20 & .24 & .26 & .25 & .27 & .20 & $.24 * *$ \\
\hline $\begin{array}{l}\text { Bequest somewhat } \\
\text { import }\end{array}$ & .59 & .61 & .58 & .57 & .58 & .57 & .58 & .58 \\
\hline Bequest not important & .20 & .19 & .18 & .18 & .17 & .17 & .22 & $.19 * *$ \\
\hline $\begin{array}{l}\text { Take very high invest } \\
\text { risks }\end{array}$ & .05 & .04 & .04 & .03 & .03 & .03 & .07 & $.04 * * *$ \\
\hline Take above avg risks & .14 & $.09 * *$ & .16 & $.12 * *$ & .21 & $.12 * * *$ & .27 & $.17 * * *$ \\
\hline Take average risks & .49 & $.38 * * *$ & .47 & $.37 * * *$ & .46 & $.39 * * *$ & .43 & $.37 * * *$ \\
\hline Take no risks & .33 & $.49 * * *$ & .33 & $.49 * * *$ & .29 & $.46^{* * *}$ & .23 & $.41 * * *$ \\
\hline Uncertain about economy & .24 & .26 & .19 & .22 & .19 & $.27 * * *$ & .26 & .27 \\
\hline Expect a bequest & .26 & $.22 * *$ & .22 & $.17 * *$ & .20 & $.15^{* * *}$ & .17 & $.15^{*}$ \\
\hline
\end{tabular}

NOTES: Uses the 1989-1992 definition of eligibility. See Appendix A for details. Standard errors are bootstrapped with 200 replications and are adjusted for imputation uncertainty.

*: difference of means statistically significant at $10 \%$ level; **: significant at $5 \%$ level; $* * *$ : significant at $1 \%$ level 
TABLE 2: Distribution of Selected Saving Variables by Income Class

\begin{tabular}{lcc}
\hline & & 1995 \\
\cline { 2 - 3 } Saving Characteristic & Eligibles & Ineligibles \\
\hline \hline & & \\
Save for retirement & .18 & .15 \\
Income: $\$ 10 \mathrm{~K}-\$ 30 \mathrm{~K}$ & .28 & $.19^{* * *}$ \\
Income: $\$ 30 \mathrm{~K}-\$ 50 \mathrm{~K}$ & .36 & .29 \\
Income: $\$ 50 \mathrm{~K}-\$ 80 \mathrm{~K}$ & .46 & .34 \\
Income: $\$ 80 \mathrm{~K}-\$ 150 \mathrm{~K}$ & & \\
& .13 & .09 \\
Most important time horizon: greater than ten years & $.12^{*}$ \\
Income: $\$ 10 \mathrm{~K}-\$ 30 \mathrm{~K}$ & .16 & $.11^{* *}$ \\
Income: $\$ 30 \mathrm{~K}-\$ 50 \mathrm{~K}$ & .19 & .21 \\
Income: $\$ 50 \mathrm{~K}-\$ 80 \mathrm{~K}$ & .21 & \\
Income: $\$ 80 \mathrm{~K}-\$ 150 \mathrm{~K}$ & & .13 \\
& .12 & $.12^{*}$ \\
Take above average financial risks for above average rewards & $.13^{* *}$ \\
Income: $\$ 10 \mathrm{~K}-\$ 30 \mathrm{~K}$ & .12 & $.18^{* * *}$ \\
Income: $\$ 30 \mathrm{~K}-\$ 50 \mathrm{~K}$ & .17 & .21 \\
Income: $\$ 50 \mathrm{~K}-\$ 80 \mathrm{~K}$ & .33 & \\
Income: $\$ 80 \mathrm{~K}-\$ 150 \mathrm{~K}$ &
\end{tabular}

NOTES: This table uses the 1995-1998 definition of eligibility. The highest and lowest income groups are excluded from the table because they contain a very small number of eligibles. Standard errors are bootstrapped with 200 replications and are adjusted for imputation uncertainty.

*: difference of means statistically significant at $10 \%$ level; **: significant at $5 \%$ level; ***: significant at $1 \%$ level 
TABLE 3: Weighted Sample Characteristics by Year and Eligibility

\begin{tabular}{|c|c|c|c|c|c|c|c|c|}
\hline \multirow[b]{2}{*}{ Characteristic (\%) } & \multicolumn{2}{|c|}{1989} & \multicolumn{2}{|c|}{1992} & \multicolumn{2}{|c|}{1995} & \multicolumn{2}{|c|}{1998} \\
\hline & Eligible & Ineligible & Eligible & Ineligible & Eligible & Ineligible & Eligible & Ineligible \\
\hline Age: $21-34$ & .34 & $.40 *$ & .34 & .37 & .34 & .33 & .30 & $.33 *$ \\
\hline Age: $35-44$ & .34 & $.26 * * *$ & .31 & .29 & .32 & .30 & .34 & $.30 * *$ \\
\hline Age: $45-54$ & .21 & .19 & .23 & .22 & .25 & .22 & .23 & .24 \\
\hline Age: $55-64$ & .11 & $.14 *$ & .12 & .12 & .09 & $.15^{* * *}$ & .13 & .13 \\
\hline Income: 1t $\$ 10 \mathrm{~K}$ & .02 & $.07^{* * *}$ & .03 & $.09 * * *$ & .03 & $.11 * * *$ & .03 & $.09 * * *$ \\
\hline Income: $\$ 10 \mathrm{~K}-\$ 30 \mathrm{~K}$ & .16 & $.35^{* * *}$ & .21 & $.38 * * *$ & .22 & $.37 * * *$ & .19 & $.35 * * *$ \\
\hline Income: $\$ 30 \mathrm{~K}-\$ 50 \mathrm{~K}$ & .31 & .27 & .30 & $.26^{*}$ & .29 & .27 & .28 & .25 \\
\hline Income: $\$ 50 \mathrm{~K}-\$ 80 \mathrm{~K}$ & .28 & $.21^{* * *}$ & .28 & $.17 * * *$ & .27 & $.16^{* * *}$ & .29 & $.21 * * *$ \\
\hline Income: $\$ 80 \mathrm{~K}-\$ 150 \mathrm{~K}$ & .19 & $.08^{* * * *}$ & .14 & $.07 * * *$ & .14 & $.07 * * *$ & .17 & $.08 * * *$ \\
\hline Income: $\$ 150 \mathrm{~K}+$ & .04 & $.02^{* * *}$ & .05 & $.03 * * *$ & .05 & $.02 * * *$ & .04 & $.02 * * *$ \\
\hline $\begin{array}{l}\text { Not a high school } \\
\text { grad }\end{array}$ & .07 & $.20^{* * *}$ & .07 & $.16^{* * * *}$ & .08 & $.16^{* * *}$ & .09 & $.18 * * *$ \\
\hline High school graduate & .29 & $.35 * *$ & .28 & .31 & .31 & .32 & .29 & .31 \\
\hline Some college & .23 & .23 & .26 & .23 & .25 & .27 & .28 & $.25^{*}$ \\
\hline College grad & .22 & $.13^{* * *}$ & .24 & $.18 * * *$ & .23 & $.15^{* * *}$ & .22 & $.15^{* * * *}$ \\
\hline Post college & .20 & $.10 * * *$ & .15 & $.12 * *$ & .13 & $.10^{* *}$ & .13 & .11 \\
\hline Single/widowed & .13 & $.17 * *$ & .16 & $.18 * *$ & .14 & $.21 * * *$ & .17 & $.21 * * *$ \\
\hline Divorced/separated & .15 & $.20^{*}$ & .13 & $.20 * * *$ & .15 & $.20 * * *$ & .16 & $.20 * *$ \\
\hline Married & .73 & $.63^{* * *}$ & .71 & $.62 * * *$ & .72 & $.59 * * *$ & .67 & $.59 * * *$ \\
\hline Family size (mean) & 3.1 & 3.0 & 2.9 & 2.9 & 2.9 & 2.8 & 2.9 & 2.9 \\
\hline Not white & .18 & $.29 * * *$ & .22 & $.29 * * *$ & .21 & $.28 * * *$ & .20 & $.31 * * *$ \\
\hline Two earners & .53 & $.35 * * *$ & .54 & $.34 * * *$ & .52 & $.32 * * *$ & .49 & $.28 * * *$ \\
\hline DB plan participant & .43 & .46 & .33 & $.42 * * *$ & .26 & $.33 * * *$ & .26 & .28 \\
\hline $\begin{array}{l}\text { Net worth (median), } \\
\text { in } 1998 \$\end{array}$ & $\$ 89,565$ & $\$ 34,802$ & $\$ 66,152$ & $\$ 27,655$ & $\$ 68,729$ & $\$ 31,332$ & $\$ 76,385$ & $\$ 26,868$ \\
\hline $\begin{array}{l}\text { Net financial assets } \\
\text { (median), in } 1998 \text { \$ }\end{array}$ & $\$ 21,171$ & $\$ 2,615$ & $\$ 20,243$ & $\$ 2,146$ & $\$ 21,430$ & $\$ 1,284$ & $\$ 26,472$ & $\$ 1,940$ \\
\hline \multicolumn{9}{|c|}{ Median 401(k) balances by income category for 1989-1998 sample (in 1998 dollars) } \\
\hline Income: 1t $\$ 10 \mathrm{~K}$ & 0 & 0 & 0 & 0 & 0 & 0 & 2400 & 0 \\
\hline Income: $\$ 10 \mathrm{~K}-\$ 30 \mathrm{~K}$ & 26 & 0 & 0 & 0 & 535 & 0 & 1400 & 0 \\
\hline Income: $\$ 30 \mathrm{~K}-\$ 50 \mathrm{~K}$ & 1313 & 0 & 2903 & 0 & 4473 & 0 & 6000 & 0 \\
\hline Income: $\$ 50 \mathrm{~K}-\$ 80 \mathrm{~K}$ & 5250 & 0 & 6966 & 0 & 7490 & 0 & 17000 & 0 \\
\hline Income: $\$ 80 \mathrm{~K}-\$ 150 \mathrm{~K}$ & 22313 & 0 & 22059 & 0 & 24075 & 0 & 35000 & 0 \\
\hline Income: $\$ 150 \mathrm{~K}+$ & 21000 & 0 & 42957 & 0 & 44940 & 0 & 60000 & 0 \\
\hline $\mathrm{N}$ & 426 & 791 & 558 & 927 & 859 & 859 & 895 & 724 \\
\hline
\end{tabular}

NOTES: Uses the 1989-1992 definition of eligibility. See Appendix A for more details. Standard errors are bootstrapped with 200 replications and are adjusted for imputation uncertainty.

$*$ : difference of means statistically significant at $10 \%$ level; **: significant at $5 \%$ level; ***: significant at $1 \%$ level 
TABLE 4:

Changes in Eligible-Ineligible Wealth, 1989-1998, Levels Specification

Without subjective saving taste measures

\begin{tabular}{|c|c|c|c|c|c|c|c|c|}
\hline \multirow{3}{*}{ Wealth measure } & \multirow{3}{*}{ Eligibility } & \multirow{2}{*}{\multicolumn{3}{|c|}{ Eligibility Interaction Terms }} & \multirow{3}{*}{ Eligibility } & \multirow{2}{*}{\multicolumn{3}{|c|}{ Eligibility Interaction Terms }} \\
\hline & & & & & & & & \\
\hline & & 1989-1992 & 1989-1995 & 1989-1998 & & 1989-1992 & 1989-1995 & 1989-1998 \\
\hline Net financial assets & $\begin{array}{l}3,631 * * * \\
(978)\end{array}$ & $\begin{array}{l}1,802 \\
(1,336)\end{array}$ & $\begin{array}{l}5,882 * * * \\
(1,416)\end{array}$ & $\begin{array}{l}11,271 * * * \\
(2,205)\end{array}$ & $\begin{array}{l}3,587 * \\
(1,973)\end{array}$ & $\begin{array}{l}1,446 \\
(1,439)\end{array}$ & $\begin{array}{l}4,830 \\
(5,558)\end{array}$ & $\begin{array}{l}7,837 \\
(6,753)\end{array}$ \\
\hline $\begin{array}{l}\text { Net financial assets excluding } \\
401(\mathrm{k}) \mathrm{s}\end{array}$ & $\begin{array}{l}102 \\
(762)\end{array}$ & $\begin{array}{l}820 \\
(828)\end{array}$ & $\begin{array}{l}1,564 \\
(1,079)\end{array}$ & $\begin{array}{l}39 \\
(1,058)\end{array}$ & $\begin{array}{l}255 \\
(863)\end{array}$ & $\begin{array}{l}742 \\
(952)\end{array}$ & $\begin{array}{l}1,356 \\
(1,144)\end{array}$ & $\begin{array}{l}-1,474 \\
(1,076)\end{array}$ \\
\hline Net worth & $\begin{array}{l}9,172 * * \\
(4010)\end{array}$ & $\begin{array}{l}-5,875 \\
(5,919)\end{array}$ & $\begin{array}{l}1,152 \\
(6,206)\end{array}$ & $\begin{array}{l}4,912 \\
(5,917)\end{array}$ & $\begin{array}{l}9,976 * * * \\
(2,959)\end{array}$ & $\begin{array}{l}-5,563 \\
(3,908)\end{array}$ & $\begin{array}{l}-3,555 \\
(4,024)\end{array}$ & $\begin{array}{l}2,215 \\
(4,511)\end{array}$ \\
\hline Net worth excluding $401 \mathrm{k}(\mathrm{s})$ & $\begin{array}{l}2,342 \\
(70,575)\end{array}$ & $\begin{array}{l}-4,394 \\
(27,933)\end{array}$ & $\begin{array}{l}516 \\
(42,855)\end{array}$ & $\begin{array}{l}-2,953 \\
(76,551)\end{array}$ & $\begin{array}{l}3,374 \\
(3,916)\end{array}$ & $\begin{array}{l}-4,319 \\
(6,032)\end{array}$ & $\begin{array}{l}-3,995 \\
(4,926)\end{array}$ & $\begin{array}{l}-6,363 \\
(4,740)\end{array}$ \\
\hline Net real assets & $\begin{array}{l}2,373 \\
(3,546)\end{array}$ & $\begin{array}{l}-3,013 \\
(7,034)\end{array}$ & $\begin{array}{l}-1,344 \\
(8,967)\end{array}$ & $\begin{array}{l}-3,665 \\
(15,627)\end{array}$ & $\begin{array}{l}1,255 \\
(1,912)\end{array}$ & $\begin{array}{l}-567 \\
(2,671)\end{array}$ & $\begin{array}{l}-1,457 \\
(2,542)\end{array}$ & $\begin{array}{l}-3,313 \\
(2,399)\end{array}$ \\
\hline Home equity & $\begin{array}{l}815 \\
(1,493)\end{array}$ & $\begin{array}{l}504 \\
(2,094)\end{array}$ & $\begin{array}{l}-65 \\
(2,591)\end{array}$ & $\begin{array}{l}-1,533 \\
(2,077)\end{array}$ & $\begin{array}{l}1,656 \\
(1,713)\end{array}$ & $\begin{array}{l}-889 \\
(2,098)\end{array}$ & $\begin{array}{l}-1,963 \\
(2,271)\end{array}$ & $\begin{array}{l}-3,510^{*} \\
(2,053)\end{array}$ \\
\hline
\end{tabular}

NOTE: Standard errors are bootstrapped with 200 replications in accordance with the SCF sample design and are adjusted for imputation uncertainty. All wealth

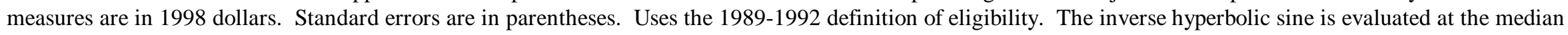
value of net financial assets $(\$ 9,000)$ for net financial assets with and without $401(\mathrm{k}) \mathrm{s}$; the median of net worth $(\$ 49,327)$ for net worth with and without 401(k)s; at $\$ 28,400$ for net real assets; and at $\$ 14,980$ for home equity. * statistically significant at the 10 percent level; ** at the 5 percent level; $* * *$ at the 1 percent level 
TABLE 5:

Changes in Eligible-Ineligible Wealth, 1989-1998, Inverse Hyperbolic Sine Specification

\begin{tabular}{|c|c|c|c|c|c|c|c|c|}
\hline \multirow{3}{*}{ Wealth measure } & \multicolumn{4}{|c|}{ Without subjective saving taste measures } & \multicolumn{4}{|c|}{ With subjective saving taste measures } \\
\hline & \multirow{2}{*}{ Eligibility } & \multicolumn{3}{|c|}{ Eligibility Interaction Terms } & \multirow{2}{*}{ Eligibility } & \multicolumn{3}{|c|}{ Eligibility Interaction Terms } \\
\hline & & 1989-1992 & 1989-1995 & 1989-1998 & & 1989-1992 & 1989-1995 & 1989-1998 \\
\hline Net financial assets & $\begin{array}{l}6,755^{* * * *} \\
(964)\end{array}$ & $\begin{array}{c}1,103 \\
(1,038)\end{array}$ & $\begin{array}{c}4,591 * * * \\
(1,334)\end{array}$ & $\begin{array}{l}2,397 * \\
(1,351)\end{array}$ & $\begin{array}{c}6,243 * * * \\
(935)\end{array}$ & $\begin{array}{c}39 \\
(1,227)\end{array}$ & $\begin{array}{c}4,483 * * * \\
(1,426)\end{array}$ & $\begin{array}{c}1,451 \\
(1,188)\end{array}$ \\
\hline $\begin{array}{l}\text { Net financial assets excluding } \\
401(\mathrm{k}) \mathrm{s}\end{array}$ & $\begin{array}{c}1,057 \\
(1,141)\end{array}$ & $\begin{array}{c}-294 \\
(1,532)\end{array}$ & $\begin{array}{c}2,344 \\
(1,626)\end{array}$ & $\begin{array}{l}-1,408 \\
(1,438)\end{array}$ & $\begin{array}{c}659 \\
(1,595)\end{array}$ & $\begin{array}{c}-933 \\
(1,667)\end{array}$ & $\begin{array}{c}2,278 \\
(1,903)\end{array}$ & $\begin{array}{l}-2,767 \\
(1,911)\end{array}$ \\
\hline Net worth & $\begin{array}{c}10,321 * * \\
(4,800)\end{array}$ & $\begin{array}{l}-2,171 \\
(5,478)\end{array}$ & $\begin{array}{c}1,074 \\
(6,113)\end{array}$ & $\begin{array}{c}7,104 \\
(5,276)\end{array}$ & $\begin{array}{l}8,888 * * \\
(3,585)\end{array}$ & $\begin{array}{l}-2,395 \\
(4,872)\end{array}$ & $\begin{array}{l}-1,291 \\
(4,985)\end{array}$ & $\begin{array}{c}2,940 \\
(5,390)\end{array}$ \\
\hline Net worth excluding 401k(s) & $\begin{array}{c}3,569 \\
(4,729) \\
\end{array}$ & $\begin{array}{l}-5,045 \\
(6,260)\end{array}$ & $\begin{array}{l}-1,498 \\
(5,562)\end{array}$ & $\begin{array}{l}-2,189 \\
(5,472)\end{array}$ & $\begin{array}{c}2,468 \\
(4,222)\end{array}$ & $\begin{array}{c}-5,232 \\
(6,111) \\
\end{array}$ & $\begin{array}{l}-4,034 \\
(5,371)\end{array}$ & $\begin{array}{l}-6,183 \\
(5,697)\end{array}$ \\
\hline Net real assets & $\begin{array}{c}2,322 \\
(3,409)\end{array}$ & $\begin{array}{c}355 \\
(3,680)\end{array}$ & $\begin{array}{l}-3,107 \\
(3,953)\end{array}$ & $\begin{array}{l}-1,848 \\
(3,743)\end{array}$ & $\begin{array}{c}-557 \\
(3,392)\end{array}$ & $\begin{array}{c}885 \\
(3,898)\end{array}$ & $\begin{array}{l}-1,520 \\
(3,901)\end{array}$ & $\begin{array}{c}-146 \\
(3,747)\end{array}$ \\
\hline Home equity & $\begin{array}{c}1,537 \\
(1,505)\end{array}$ & $\begin{array}{l}-1,167 \\
(1,868)\end{array}$ & $\begin{array}{c}-572 \\
(1,981)\end{array}$ & $\begin{array}{c}-806 \\
(2,013) \\
\end{array}$ & $\begin{array}{c}1,193 \\
(1,581)\end{array}$ & $\begin{array}{c}-572 \\
(2,004) \\
\end{array}$ & $\begin{array}{l}-1,691 \\
(2,230)\end{array}$ & $\begin{array}{c}99 \\
(2,178) \\
\end{array}$ \\
\hline
\end{tabular}

NOTE: Standard errors are bootstrapped with 200 replications in accordance with the SCF sample design and are adjusted for imputation uncertainty. All wealth measures are in 1998 dollars. Standard errors are in parentheses. Uses the 1989-1992 definition of eligibility. The inverse hyperbolic sine is evaluated at the median value of net financial assets $(\$ 9,000)$ for net financial assets with and without $401(\mathrm{k}) \mathrm{s}$; the median of net worth $(\$ 49,327)$ for net worth with and without $401(\mathrm{k}) \mathrm{s}$; at $\$ 28,400$ for net real assets; and at $\$ 14,980$ for home equity. * statistically significant at the 10 percent level; $* *$ at the 5 percent level; *** at the 1 percent level 
TABLE 6:

Comparison of 1989-1998 and 1995-1998 Eligibility Definitions

IHS specification with saving taste variables

\begin{tabular}{|c|c|c|c|c|}
\hline \multirow[b]{2}{*}{ Wealth Measure } & \multicolumn{2}{|c|}{ 1989-1992 definition } & \multicolumn{2}{|c|}{ 1995-1998 definition } \\
\hline & Eligibility & $\begin{array}{l}\text { Eligibility* } \\
\text { Year }=98\end{array}$ & Eligibility & $\begin{array}{c}\text { Eligibility* } \\
\text { Year }=98\end{array}$ \\
\hline Net financial assets & $\begin{array}{l}10,371 * * * \\
(1,132)\end{array}$ & $\begin{array}{l}-2,733^{*} \\
(1,504)\end{array}$ & $\begin{array}{l}8,405 * * * \\
(1,065)\end{array}$ & $\begin{array}{l}-726 \\
(1,546)\end{array}$ \\
\hline $\begin{array}{l}\text { Net financial assets excluding } \\
401(\mathrm{k}) \mathrm{s}\end{array}$ & $\begin{array}{l}2,720 * * \\
(1,257)\end{array}$ & $\begin{array}{l}-4,213 * * \\
(1,777)\end{array}$ & $\begin{array}{l}1,403 \\
(1,056)\end{array}$ & $\begin{array}{l}-2,553 \\
(1,587)\end{array}$ \\
\hline Net worth & $\begin{array}{l}9,500 * * * \\
(2,982)\end{array}$ & $\begin{array}{l}3,356 \\
(3,779)\end{array}$ & $\begin{array}{l}5,887 * \\
(3,355)\end{array}$ & $\begin{array}{l}5,341 \\
(4,185)\end{array}$ \\
\hline Net worth excluding $401(\mathrm{k}) \mathrm{s}$ & $\begin{array}{l}-44 \\
(2,648)\end{array}$ & $\begin{array}{l}-3,250 \\
(4036)\end{array}$ & $\begin{array}{l}-1,116 \\
(3,121)\end{array}$ & $\begin{array}{l}-1,279 \\
(3,971)\end{array}$ \\
\hline Net real assets & $\begin{array}{l}-1,627 \\
(1,777)\end{array}$ & $\begin{array}{l}1,069 \\
(2,480)\end{array}$ & $\begin{array}{l}-1,312 \\
(1,904)\end{array}$ & $\begin{array}{l}682 \\
(2,689)\end{array}$ \\
\hline Home equity & $\begin{array}{l}-547 \\
(1,162)\end{array}$ & $\begin{array}{l}181 \\
(1,776)\end{array}$ & $\begin{array}{l}-445 \\
(1,213)\end{array}$ & $\begin{array}{l}-208 \\
(1,751)\end{array}$ \\
\hline
\end{tabular}

NOTE: Standard errors are bootstrapped with 200 replications in accordance with the SCF sample design and are adjusted for imputation uncertainty. All wealth measures are in 1998 dollars. Standard errors are in parentheses. The inverse hyperbolic sine transformation is evaluated at the median value of net financial assets $(\$ 9,000)$ for net financial assets with and without $401(\mathrm{k}) \mathrm{s}$; the median of net worth $(\$ 49,327)$ for net worth with and without $401(\mathrm{k}) \mathrm{s}$; at $\$ 28,400$ for net real assets; and at $\$ 14,980$ for home equity. * statistically significant at the 10 percent level; ** at the 5 percent level; *** at the 1 percent level 
TABLE 7: Changes in Wealth within Eligibility and Income Groups, 1995-1998

\begin{tabular}{|c|c|c|c|c|}
\hline \multirow[b]{2}{*}{ Wealth Measure } & \multicolumn{2}{|c|}{ IHS } & \multicolumn{2}{|c|}{ Levels } \\
\hline & $\begin{array}{l}\text { Eligibility } \\
\text { Marginal } \\
\text { Effect }\end{array}$ & $\begin{array}{l}\text { Eligibility* } \\
\text { Year }=98\end{array}$ & $\begin{array}{l}\text { Eligibility } \\
\text { Marginal } \\
\text { Effect }\end{array}$ & $\begin{array}{l}\text { Eligibility* } \\
\text { Year }=98\end{array}$ \\
\hline \multicolumn{5}{|l|}{ Net financial assets } \\
\hline Income: $\$ 10,000-\$ 30,000$ & $\begin{array}{l}1,176^{* * *} \\
(316)\end{array}$ & $\begin{array}{l}-672 \\
(420)\end{array}$ & $\begin{array}{l}2,067 * \\
(1,084)\end{array}$ & $\begin{array}{l}-1,371 \\
(2,443)\end{array}$ \\
\hline Income: $\$ 30,000-\$ 50,000$ & $\begin{array}{l}10,384 * * * \\
(2,262)\end{array}$ & $\begin{array}{l}-598 \\
(3,115)\end{array}$ & $\begin{array}{l}6,442 * * * * \\
(2,220)\end{array}$ & $\begin{array}{l}1,893 \\
(2,955)\end{array}$ \\
\hline Income: $\$ 50,000-\$ 80,000$ & $\begin{array}{l}18,611 \text { *** } \\
(5,455)\end{array}$ & $\begin{array}{l}1,910 \\
(9,799)\end{array}$ & $\begin{array}{l}13,399 \text { *** } \\
(2,843)\end{array}$ & $\begin{array}{l}6,262 \\
(6,758)\end{array}$ \\
\hline \multicolumn{5}{|l|}{$\begin{array}{l}\text { Net financial assets excluding } \\
401(\mathrm{k}) \mathrm{s}\end{array}$} \\
\hline Income: $\$ 10,000-\$ 30,000$ & $\begin{array}{l}349 \\
(304)\end{array}$ & $\begin{array}{l}-389 \\
(375)\end{array}$ & $\begin{array}{l}330 \\
(6,183)\end{array}$ & $\begin{array}{l}-613 \\
(5,499)\end{array}$ \\
\hline Income: $\$ 30,000-\$ 50,000$ & $\begin{array}{l}4,164 * \\
(2,327)\end{array}$ & $\begin{array}{l}-4,411 \\
(3,440)\end{array}$ & $\begin{array}{l}1,187 \\
(6,713)\end{array}$ & $\begin{array}{l}-1,102 \\
(3,373)\end{array}$ \\
\hline Income: $\$ 50,000-\$ 80,000$ & $\begin{array}{l}-1,655 \\
(7,584)\end{array}$ & $\begin{array}{l}-7,332 \\
(10,725)\end{array}$ & $\begin{array}{l}1,185 \\
(2882)\end{array}$ & $\begin{array}{l}-8,403 \\
(12,331)\end{array}$ \\
\hline \multicolumn{5}{|l|}{ Net worth } \\
\hline Income: $\$ 10,000-\$ 30,000$ & $\begin{array}{l}3,010^{*} \\
(1,751)\end{array}$ & $\begin{array}{l}207 \\
(2,871)\end{array}$ & $\begin{array}{l}2,908 \\
(2,291)\end{array}$ & $\begin{array}{l}-1,270 \\
(3,443)\end{array}$ \\
\hline Income: $\$ 30,000-\$ 50,000$ & $\begin{array}{l}4,302 \\
(5,968)\end{array}$ & $\begin{array}{l}10,275 \\
(7,287)\end{array}$ & $\begin{array}{l}1,350 \\
(5,448)\end{array}$ & $\begin{array}{l}10,974 \\
(8,010)\end{array}$ \\
\hline Income: $\$ 50,000-\$ 80,000$ & $\begin{array}{l}13,589 \\
(12,129)\end{array}$ & $\begin{array}{l}-12,892 \\
(15,557)\end{array}$ & $\begin{array}{l}15,944 \\
(12,397)\end{array}$ & $\begin{array}{l}3,091 \\
(17,438)\end{array}$ \\
\hline \multicolumn{5}{|l|}{ Net worth excluding $401(\mathrm{k}) \mathrm{s}$} \\
\hline Income: $\$ 10,000-\$ 30,000$ & $\begin{array}{l}1,506 \\
(1,823)\end{array}$ & $\begin{array}{l}-495 \\
(2,374)\end{array}$ & $\begin{array}{l}-650 \\
(2786)\end{array}$ & $\begin{array}{l}560 \\
(4,448)\end{array}$ \\
\hline Income: $\$ 30,000-\$ 50,000$ & $\begin{array}{l}-1,623 \\
(5,656)\end{array}$ & $\begin{array}{l}2,976 \\
(7,134)\end{array}$ & $\begin{array}{l}-1,396 \\
(8275)\end{array}$ & $\begin{array}{l}3,513 \\
(8,624)\end{array}$ \\
\hline Income: $\$ 50,000-\$ 80,000$ & $\begin{array}{l}-6,138 \\
(11,542)\end{array}$ & $\begin{array}{l}-20,886 \\
(15,681)\end{array}$ & $\begin{array}{l}-2,645 \\
(11259)\end{array}$ & $\begin{array}{l}-11,871 \\
(16,211)\end{array}$ \\
\hline \multicolumn{5}{|l|}{ Home equity } \\
\hline Income: $\$ 10,000-\$ 30,000$ & $\begin{array}{l}122 \\
(1,616)\end{array}$ & $\begin{array}{l}-151 \\
(1,727)\end{array}$ & $\begin{array}{l}161 \\
(887)\end{array}$ & $\begin{array}{l}-152 \\
(1,160)\end{array}$ \\
\hline Income: $\$ 30,000-\$ 50,000$ & $\begin{array}{l}-4,923 \\
(30,362)\end{array}$ & $\begin{array}{l}5,402 \\
(87,020)\end{array}$ & $\begin{array}{l}-1,084 \\
(1,748)\end{array}$ & $\begin{array}{l}2,211 \\
(2,098)\end{array}$ \\
\hline Income: $\$ 50,000-\$ 80,000$ & $\begin{array}{l}5,819 \\
(17,070)\end{array}$ & $\begin{array}{l}-9,665 \\
(51,435)\end{array}$ & $\begin{array}{l}4,502 \\
(5,755)\end{array}$ & $\begin{array}{l}-6,886 \\
(7,970)\end{array}$ \\
\hline
\end{tabular}

NOTE: Standard errors are bootstrapped with 200 replications in accordance with the SCF sample design and are adjusted for imputation uncertainty. All wealth measures are in 1998 dollars. Standard errors are in parentheses. The specification includes subjective saving taste measures. The IHS transformation is evaluated at the median level of each wealth measure. ${ }^{*}$ statistically significant at the 10 percent level; ** at the 5 percent level; *** at the 1 percent level 
TABLE 8:

Standard Errors Comparison

Net Financial Assets with Saving Taste Variables Specification

\begin{tabular}{|c|c|c|c|c|}
\hline $\begin{array}{l}\text { Eligible*Income* } \\
\text { Year }=98\end{array}$ & Coefficient & $\begin{array}{c}\text { Analytical standard } \\
\text { errors }\end{array}$ & $\begin{array}{c}\text { Bootstrapped } \\
\text { standard errors }\end{array}$ & $\begin{array}{c}\text { Bootstrapped and } \\
\text { imputation-adjusted } \\
\text { standard errors } \\
\end{array}$ \\
\hline \multicolumn{5}{|l|}{ Levels specification } \\
\hline Income: $\$ 10 \mathrm{~K}-30 \mathrm{~K}$ & $-1,371$ & 3,039 & 1,250 & 2,443 \\
\hline Income: $\$ 30 \mathrm{~K}-50 \mathrm{~K}$ & 1,893 & 3,049 & 2,311 & 2,955 \\
\hline Income: $\$ 50 \mathrm{~K}-80 \mathrm{~K}$ & 6,262 & 3,279 & 4,948 & 6,758 \\
\hline Income: $\$ 80 \mathrm{~K}-\$ 150 \mathrm{~K}$ & -714 & 4,585 & 20,490 & 24,143 \\
\hline $\begin{array}{l}\text { Income: greater than } \\
\$ 150 \mathrm{~K}\end{array}$ & $-265,783$ & 5,118 & 193,363 & 215,887 \\
\hline \multicolumn{5}{|l|}{ IHS specification } \\
\hline Income: $\$ 10 \mathrm{~K}-30 \mathrm{~K}$ & -624 & 334 & 165 & 390 \\
\hline Income: $\$ 30 \mathrm{~K}-50 \mathrm{~K}$ & -81 & 336 & 301 & 423 \\
\hline Income: $\$ 50 \mathrm{~K}-80 \mathrm{~K}$ & 73 & 359 & 309 & 373 \\
\hline Income: $\$ 80 \mathrm{~K}-\$ 150 \mathrm{~K}$ & 147 & 501 & 465 & 515 \\
\hline $\begin{array}{l}\text { Income: greater than } \\
\$ 150 \mathrm{~K}\end{array}$ & -236 & 559 & 430 & 673 \\
\hline
\end{tabular}

TABLE 9:

Adding pension assets to the wealth measure IHS specification with saving taste coefficients

\begin{tabular}{clll}
\hline Wealth Measure & Eligibility Coefficient & Eligibility*Year=98 \\
\hline \hline Net financial assets & & \\
& & \\
Income: $\$ 10,000-\$ 30,000[\$ 400]$ & $(306)$ & -664 \\
& $10,173^{* * *}$ & $(422)$ \\
Income: $\$ 30,000-\$ 50,000[\$ 7,300]$ & $(2,280)$ & -308 \\
& $18,613^{* * *}$ & $(3,180)$ \\
Income: $\$ 50,000-\$ 80,000[\$ 26,250]$ & $(5,919)$ & 2,442 \\
Net financial and pension assets & & $(10,558)$ \\
Income: $\$ 10,000-\$ 30,000[\$ 1,968]$ & $2,183^{* * *}$ & -472 \\
& $(844)$ & $(812)$ \\
Income: $\$ 30,000-\$ 50,000[\$ 20,680]$ & $20,132^{* * *}$ & 765 \\
& $(4,567)$ & $(7,827)$ \\
Income: $\$ 50,000-\$ 80,000[\$ 65,821]$ & 32,959 & 4,677 \\
& $(20,267)$ & $(18,965)$ \\
\hline
\end{tabular}

NOTE: Standard errors are bootstrapped with 200 replications in accordance with the SCF sample design and are adjusted for imputation uncertainty. All wealth measures are in 1998 dollars. Standard errors are in parentheses. The inverse hyperbolic sine transformation is evaluated at the median level of each wealth measure.

* statistically significant at the 10 percent level; ** at the 5 percent level; *** at the 1 percent level 